\title{
Quantitative analysis of the time-course of viral DNA forms during the HIV-1 life cycle
}

\author{
Soundasse Munir ${ }^{\dagger}$, Sylvain Thierry ${ }^{\dagger}$, Frédéric Subra, Eric Deprez and Olivier Delelis ${ }^{*}$
}

\begin{abstract}
Background: HIV-1 DNA is found both integrated in the host chromosome and unintegrated in various forms: linear $\left(D N A_{L}\right.$ ) or circular (1-LTRC, 2-LTRc or products of auto-integration). Here, based on pre-established strategies, we extended and characterized in terms of sensitivity two methodologies for quantifying 1-LTRC and DNA respectively, the latter being able to discriminate between unprocessed or 3'-processed DNA.

Results: Quantifying different types of viral DNA genome individually provides new information about the dynamics of all viral DNA forms and their interplay. For DNA $A_{L}$, we found that the 3'-processing reaction was efficient during the early stage of the replication cycle. Moreover, strand-transfer inhibitors (Dolutegravir, Elvitegravir, Raltegravir) affected 3'-processing differently. The comparisons of 2-LTRC accumulation mediated by either strand-transfer inhibitors or catalytic mutation of integrase indicate that 3'-processing efficiency did not influence the total 2-LTRC accumulation although the nature of the LTR-LTR junction was qualitatively affected. Finally, a significant proportion of 1-LTRc was generated concomitantly with reverse transcription, although most of the 1-LTRc were produced in the nucleus.

Conclusions: We describe the fate of viral DNA forms during HIV-1 infection. Our study reveals the interplay between various forms of the viral DNA genome, the distribution of which can be affected by mutations and by inhibitors of HIV-1 viral proteins. In the latter case, the quantification of 3'-processed DNA in infected cells can be informative about the mechanisms of future integrase inhibitors directly in the cell context.
\end{abstract}

Keywords: HIV-1, 3'-processing, 1-LTR circles, Integrase, Strand transfer inhibitors

\section{Background}

After HIV-1 particles enter their target cells, reverse transcriptase converts HIV-1 viral RNA into a doublestranded linear DNA $\left(\mathrm{DNA}_{\mathrm{L}}\right)$. The resulting $\mathrm{DNA}_{\mathrm{L}}$ moves into the nucleus as a component of the pre-integration complex (PIC) and then integrates into the host cell genome [1]. Integration of $\mathrm{DNA}_{\mathrm{L}}$ is essential for a productive infection $[2,3]$. This process requires the integrase activity for the 3 '-processing reaction at both LTR (Long Terminal Repeat) extremities of the blunt (or unprocessed) DNA, named $\mathrm{uDNA}_{\mathrm{L}}$, leading to 3 '-processed linear DNA $\left(\mathrm{pDNA}_{\mathrm{L}}\right)$ [4]. This reaction involves the removal of a dinucleotide after the canonical $5^{\prime}$-CA found in all retroviruses. The integrase-mediated integration of $\mathrm{pDNA}_{\mathrm{L}}$ into the host cell genome can be efficiently inhibited by integrase strand-transfer inhibitors (INSTIs)

\footnotetext{
* Correspondence: delelis@lbpa.ens-cachan.fr

†Equal contributors

LBPA, ENS Cachan, CNRS, Cachan, France
}

[5], including Raltegravir (RAL), Dolutegravir (DTG) and Elvitegravir (EVG); this inhibition is similar to that associated with inactivation of the catalytic triad of integrase (for example due to D116N/A mutation [6,7]). It is important to note that the INSTI compounds, unlike catalytic mutants, are not supposed to influence the 3 '-processing reaction and inhibit the strand transfer reaction of the integration process only [8]. It is intriguing to note that the context of catalytic mutant or INSTI treatment lead to similar 2-LTRc accumulation despite differentially affecting the $3^{\prime}$-processing step $[9,10]$. One possible explanation is that although INSTI are specific strand transfer inhibitors in vitro, they may affect the 3 '-processing reaction in the cell context. Alternatively, the formation of 2-LTRc could be compatible with both types of viral DNA ends, processed or unprocessed leading to both 2-LTRc encompassing a perfect palindromic junction (resulting from ligation of blunt extremities) and others with an imperfect palindromic junction (most likely originating from 
auto-integration [11]). However, this issue remains unresolved because quantitative and sensitive data about the fate of linear HIV-1 DNA, more particularly for separately quantifying the two principal forms of linear DNA $\left(\mathrm{pDNA}_{\mathrm{L}}\right.$ and $\mathrm{uDNA} \mathrm{L}_{\mathrm{L}}$ ), are not well-established.

In addition to $\mathrm{DNA}_{\mathrm{L}}\left(=\mathrm{pDNA}_{\mathrm{L}}+\mathrm{uDNA} \mathrm{L}_{\mathrm{L}}\right)$, unintegrated forms of HIV-1 DNA include DNA circles which harbor one or two LTR (1-LTRc and 2-LTRc, respectively); 1-LTRc is formed by circularization of $\mathrm{DNA}_{\mathrm{L}}$ by homologous recombination and 2-LTRc by the NonHomologous End Joining (NHEJ) pathway [12-14]. Other circular forms, resulting from auto-integration, could also be detected using PCR assays [15]. For instance, in the context of 2-LTRc, auto-integration events lead to 2-LTRc harboring imperfect palindromic junction in contrast to 2-LTRc originating from NHEJ [11]. Although 2-LTRc are considered to be deadend molecules, 1-LTRc may sustain viral gene expression $[13,16]$.

To date, few quantitative data about the intracellular localization of HIV-1 DNA species are available. Moreover, the relative abundance of the different viral DNA forms is dynamic and is dependent of viral conditions of infection. The intracellular localization of viral genomes has been determined by Southern blotting experiments [17]. However, this approach suffers from a lack of detection sensitivity and the distribution of viral forms can be assessed only qualitatively. Although real-time PCR-based protocols have been developed for accurately quantifying the integrated, 2LTRc and total viral DNA forms [18,19], no method for accurate quantification of 1-LTRc is available [20]. Concerning $\mathrm{DNA}_{\mathrm{L}}$, based on previous established strategy [21], we explored the optimal conditions for reliable quantification and further characterized the quantification of $\mathrm{pDNA}_{\mathrm{L}}$ and $\mathrm{uDNA} \mathrm{L}_{\mathrm{L}}$, and compared the sensitivity of this approach to that of Southern blotting.

We report original information related to the dynamics of all viral DNA genomes, and the efficiency and localization of the 3 '-processing reaction. We also described the action of the anti-integrase compounds. Mainly, we found that $3^{\prime}$-processing is an efficient process (80\% of linear DNA is processed) occurring in cytoplasm at early stage of the replication cycle, concomitant with or soon after reverse transcription. Furthermore, we show that INSTIs at sub-micromolar concentrations that fully prevent integration do not inhibit the 3 '-processing reaction in the context of viral infection. Regarding circular forms, we observed that 1-LTRc are mainly formed in the nucleus but, unlike 2-LTRc which are exclusively generated in the nucleus, a small but significant proportion (10\%) of 1-LTRc are formed in the cytoplasm.

\section{Results}

To extend the quantitative analysis to other HIV-1 DNA forms, we addressed two quantitative protocols based on real-time PCR for quantifying linear viral DNA and 1-LTRc. Regarding linear viral DNA, we used a linkermediated PCR method based on a qualitative approach described by Pierson and colleagues [22] (see Methods). This method involves using the 11TAb linker to detect total HIV-1 linear DNA (i.e. the processed, $\mathrm{pDNA}_{\mathrm{L}}$, and unprocessed, $\left.u D N A_{L}\right)$ and the $11 \mathrm{~b}$ linker to detect $\mathrm{uDNA}_{\mathrm{L}}$ only (Figure 1). The quantification of both linear DNA forms was reliable as attested by the good performance in terms of efficiency and sensitivity (90\% efficiency over a 7-log range and a sensitivity of 100 DNA copies per $10^{6}$ cells) (Figure 1). This method was more sensitive than Southern blotting, for which the limit of detection was $10^{5}$ copies per $10^{6}$ cells (Additional file 1: Figure S1A). Thus, this method is suitable for quantitative analysis of the 3 '-processing reaction in the virological context. It is important to note that, following infection, the overhanging dinucleotide of the processed HIV-1 DNA is 5'-AC (for the LTR5' or LTR3') and not the $5^{\prime}$-TA found in $\mathrm{pDNA}_{\mathrm{L}}$ (resulting from the NdeI/ AatII digestion of pLIN-HIV-NdeI). Thus, in order to extend the quantification procedure for $\mathrm{DNA}_{\mathrm{L}}$ in the virological context, the linker 11GTb (with a TG-5' overhanging; Additional file 1: Table S1A) was used rather than 11TAb in further experiments described below (the linker used for $\mathrm{uDNA}_{\mathrm{L}}$ quantification was still 11b). The efficiency of the method using the linker $11 \mathrm{GTb}$ was verified (Additional file 1: Figure S1B).

Southern blotting analyses indicate that the amounts of 1-LTRc during infection are not negligible: 1-LTRc are more abundant than 2-LTRc and are present in similar amount compared to $\mathrm{DNA}_{\mathrm{L}}$ [23]. Thus, their accurate quantification is required to understand the relationships between the different viral DNA forms. Despite previous efforts to develop PCR-based methods for quantifying 1 -LTRc $[24,25]$, it has been reported that these methods are inaccurate [20]. Indeed, primers hybridizing in the env and gag genes could lead to amplification of the LTR-LTR region in 2-LTRc and amplification of $\mathrm{DNA}_{\mathrm{L}}$ via LTR recombination [20] (see also Figure 2A). We therefore optimized an improved quantitative PCR protocol for 1-LTRc by addressing as a first criterion the detection of undesirable abovementioned amplification products. We found that the elongation time was the crucial parameter to ensure specific amplification of 1-LTRc. Among the different tested conditions (modulation of the elongation time of the PCR), we found that $25 \mathrm{~s}$ was optimal (Additional file 1: Figure S2). Using p1-LTR for establishing a standard curve, we found that our protocol gave good amplification $(92.5-100 \%)$ and provided sensitive detection (200 


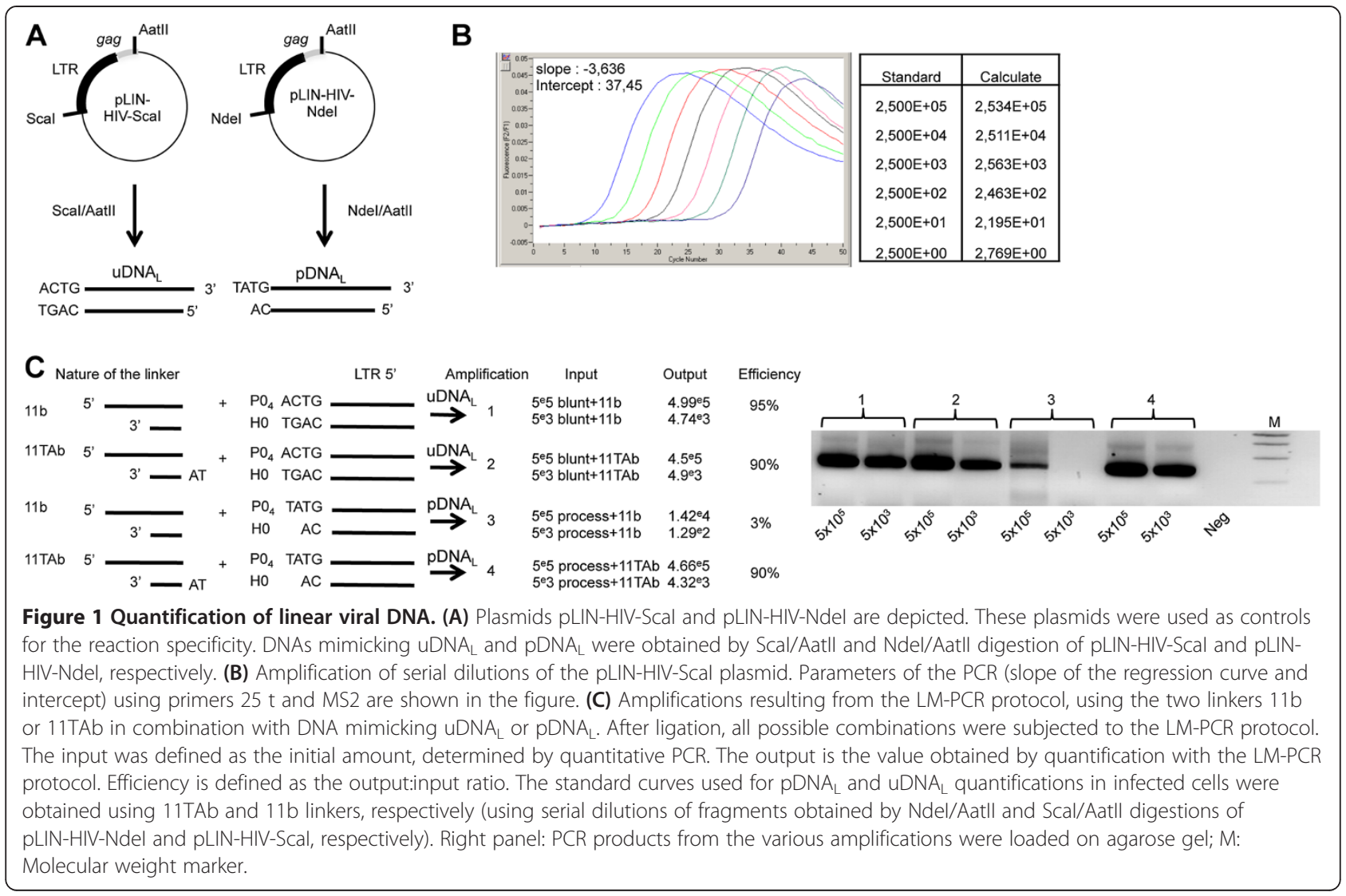

copies $/ 10^{6}$ cells) of 1 -LTRc (Figure 2). We then addressed the question of detection specificity and the influence of 2-LTRc content on the 1-LTRc quantification during infection by using Nalm-6 (ligase- $4^{+}$) and Nalm-114 (ligase-4') cells infected with HIV-1 $\Delta$ env viruses, either WT or D116N (a catalytic mutant of integrase [7]) [26]. It was previously described by Southern blot analysis that ligase-4 is involved in the formation of 2-LTRc only (not 1-LTRc) and that the D116N mutation leads to a substantial increase in the 2-LTRc content in the ligase $-4^{+}$context due to integration defect (to a much less extent the 1-LTRc content) [27]. Quantifications of total viral DNA as well as each circular viral DNA form (1-LTRc or 2-LTRc) were performed at different times post-infection (p.i.) (Figure 2D). Our results confirmed the strong inhibition (by a 40-fold factor) of 2-LTRc formation for both WT and D116N in Nalm-114 compared to Nalm-6 [12]. The amounts of 1-LTRc were similar in both cell lines infected by WT or D116N. This result confirms that the ligase 4 is not involved in the formation of 1-LTRc, consistent with the qualitative results reported by Li and colleagues [28]. Importantly, the amount of 1-LTRc was found to be similar regardless of the amount of 2-LTRc accumulated (compare in Figure 2D Nalm-6 and Nalm-114 infected by D116N). This confirms that our quantitative approach allows an accurate quantification of 1-LTRc in the cellular context without any bias due to the presence of 2-LTRc.

Based on (i) previously validated PCR-based protocols for quantification of total viral DNA, 2-LTRc and integrated viral DNA and (ii) the improvement described above for quantification of 1-LTRc, $\mathrm{uDNA}_{\mathrm{L}}$ and $\mathrm{pDNA}_{\mathrm{L}}$, we established the time course of these $\mathrm{HIV}-1$ genomes during infection.

\section{Exhaustive time course study of viral DNA forms during infection}

We used MT4 cells infected with $\Delta$ env viruses (WT+/RAL or D116N) as a model system to study the kinetics of viral DNA forms (integrated viral DNA, 1-LTRc, 2LTRc and $\mathrm{DNA}_{\mathrm{L}}$ ) during a single-round of viral replication [26]. Viral DNA was analyzed at different times p.i.. In the WT context, total HIV-1 DNA level peaked $8 \mathrm{~h}$ p.i. and then decreased steeply until $32 \mathrm{~h}$ p.i. (Figure $3 \mathrm{~A}$ ) to match the integrated HIV-1 DNA level (Figure 3B) as already reported [18]. Integration inhibition by RAL or due to the $\mathrm{D} 116 \mathrm{~N}$ mutation did not influence reverse transcription as total viral DNA synthesis was similar to the WT condition (Figures $3 \mathrm{~A}$ and $\mathrm{B}$ ). Under integration inhibition conditions, 2-LTRc accumulated to reach a maximum at $24 \mathrm{~h}-32 \mathrm{~h}$ p.i. whereas the amount of 2LTRc in the WT context remained low (Figure $3 \mathrm{C}$ ), as 


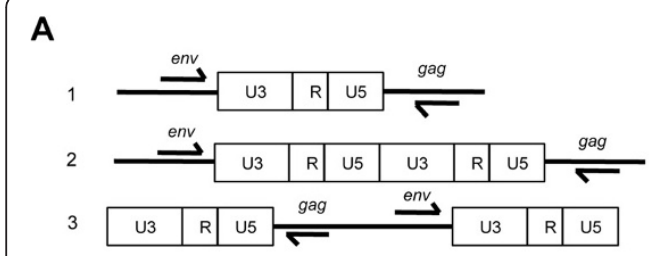

B
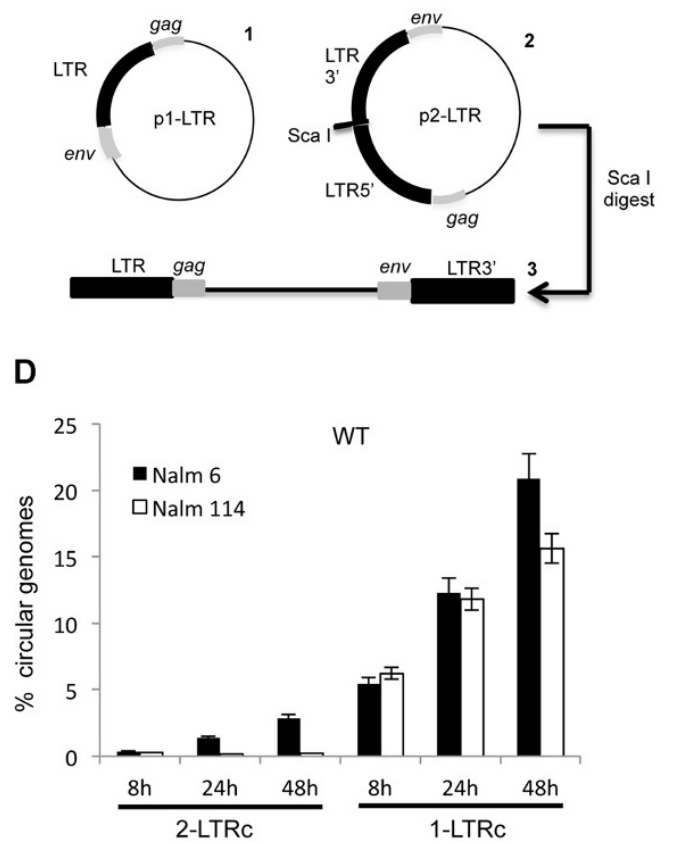
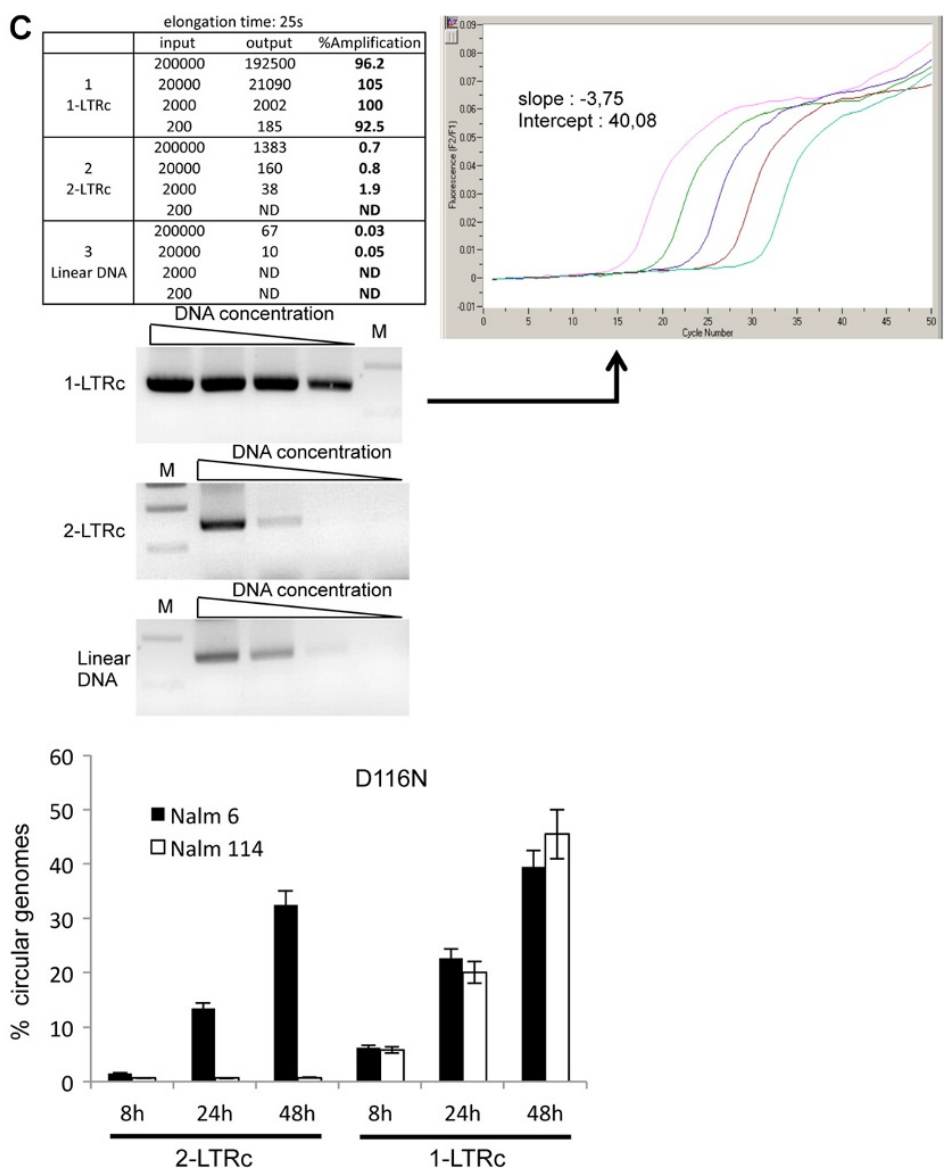

Figure 2 Quantification of 1-LTRc. (A) Possible amplifications from the various substrates found in infected cells with primers used for 1-LTRC quantification. 1: 1-LTRc; 2: 2-LTRc and 3: linear viral DNA. (B) Plasmids (1: p1-LTR and 2: p2-LTR) used as controls. Linear DNA (3) was obtained by Scal digestion of P2-LTR. (C) Amplification of serial dilutions of p1-LTR using the protocol for 1-LTRc amplification. Amplification of known amounts of p1-LTR (1), p2-LTR (2) and linear DNA (3) using the protocol for 1-LTRc quantification. The results are reported in the table, for an elongation time of $25 \mathrm{~s}$. Input: initial amount of target. Output: amount measured with the 1-LTRc protocol. \%Amplification calculation is based on the output:input ratio. The plot shows the amplification results with known amounts of P1-LTR. The PCR products obtained with the various substrates were loaded onto an agarose gel (shown below the table). M: Molecular weight marker. (D) 1-LTRc quantification is not influenced by the presence of 2-LTRC. Nalm6 and Nalm114 cells were infected with VSV-G-pseudotyped NLENG1-ES-IRES WT (left panel) or NLENG1-ES-IRES D116N (right panel). At different times post-infection, the percentages of 2-LTRC and 1-LTRc were determined in Nalm6 (ligase-4+) (black columns) and Nalm114 (ligase-4-) (white columns) cell lines. Each value corresponds to an average of five to six independent experiments and confidence intervals analysis are shown for a $p$ value $<0.05$.

previously reported $[8,29]$. The study of circular forms behavior in the different conditions reveals two interesting observations. The first one is related to 1-LTRc: In the short time scale p.i. (until $5 \mathrm{~h}$ ), significant 1-LTRc amount was detected while, in the same time, no 2LTRC was detected. This result is intriguing because in a longer time scale p.i. (after $5 \mathrm{~h}$ ), 1-LTRc synthesis followed 2-LTRc synthesis. The reason for such an apparent discrepancy will be further discussed (see next section). The second one concerns the similar accumulation of 2-LTRc in both conditions of IN inhibition: presence of RAL or D116N mutation. This observation is intriguing in first approximation because it is known that RAL and D116N differentially affect $3{ }^{\prime}$-processing.
Two hypotheses may explain such observations: (i) Either RAL behaves differentially in the virological context. (ii) The accumulated 2-LTRc are qualitatively different. Until now, 2-LTRc accumulation was studied using primers spanning the LTR-LTR junction, such that the nature of the LTR-LTR junction (representing global 2LTRc) cannot be investigated. Recently, De Iaco et al. used oligonucleotides hybridizing at the palindromic junction, and discriminated 2-LTRc harboring a perfect palindromic sequence at the LTR-LTR junction (resulting from ligation of unprocessed extremities) from those harboring a deletion or insertion (imperfect palindrome, for instance formed by auto-integration) [11]. Using this setting, we confirm that the accumulation of global 2-LTRc 


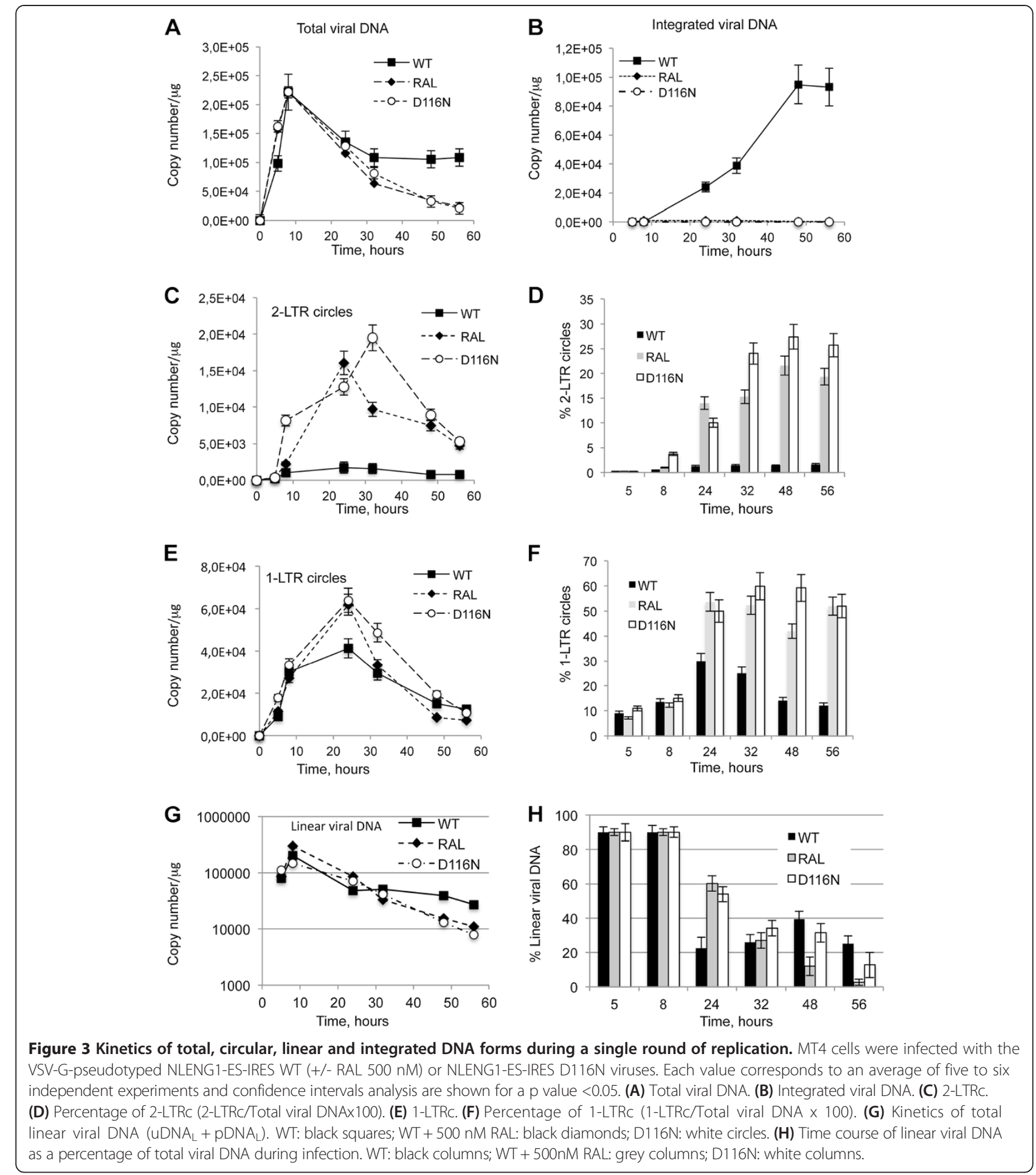

was similar when integration was impaired by RAL treatment or by D116N mutation (Figure 4A). However, the accumulation of 2-LTRc harboring a perfect palindromic junction was similar, at about $40 \%$, for WT and RAL conditions, but much higher, about $80 \%$, in the case of D116N (Figure 4B). In conclusion, even though
3 '-processing influences the nature of the palindromic junction, the global amount similarly increases when integration is inhibited, regardless of the 3 '-processing status.

Yan et al. have shown that auto-integration occurs during reverse transcription leading to circular forms 

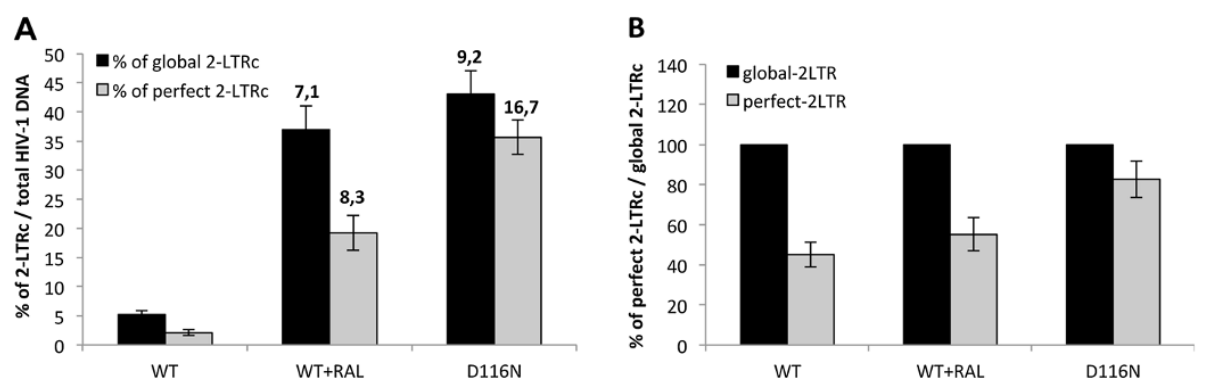

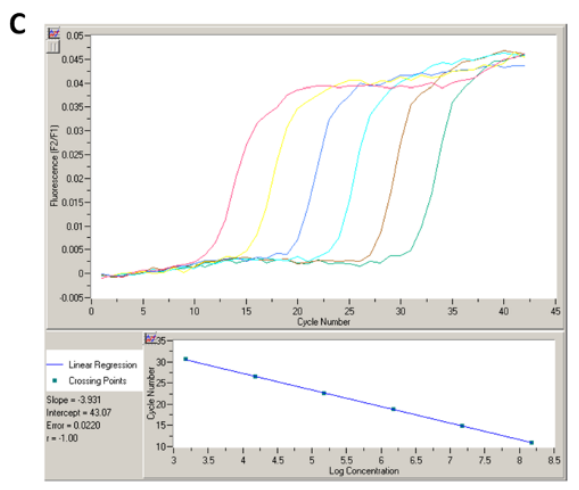

Standard curve using primers and probes for quantification of 2-LTRc harboring a perfect LTR-LTR junction

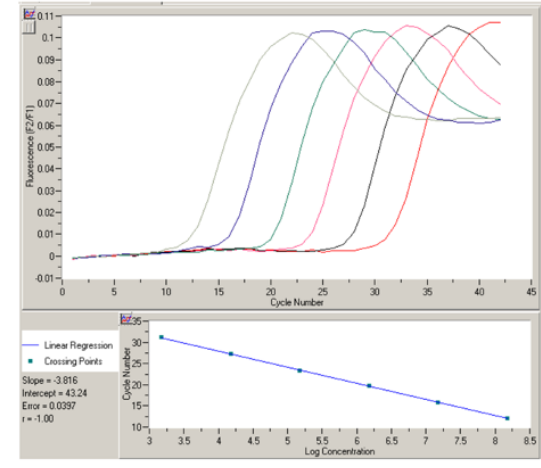

Standard curve using primers and probes for quantification of 2-LTRc (global i.e. harboring a perfect or imperfect LTRLTR junction)

Figure 4 Characterization of the nature of the LTR-LTR junction. MT4 cells were infected with the VSV-G-pseudotyped NLENG1-ES-IRES WT (+/- RAL $500 \mathrm{nM}$ ) or NLENG1-ES-IRES D116N viruses. Each value corresponds to an average of five to six independent experiments and confidence intervals analysis are shown for a p value $<0.05$. (A) 2-LTRc as a percentage of total HIV-1 DNA $24 \mathrm{~h}$ post-infection (black column, global 2-LTRc and grey column, 2-LTRC harboring a perfect LTR-LTR junction). The fold increase in the amount of 2-LTRc (between integration defective conditions (WT + RAL and D116N) and the WT) is indicated at the top of the columns. (B) 2-LTRc harboring a perfect palindromic sequence as a percentage of total 2-LTRC in each condition of infection (WT, WT + RAL and D116N). (C) Standard curves with p2-LTR using primers and probes for quantification of 2-LTRC harboring a perfect LTR-LTR junction (left panel) and for quantification of total 2-LTRC (right panel).

detected only during WT infection and not with RAL or the D116N/A mutant. Indeed, RAL or the D116N/A mutation abolish the auto-integration activity of integrase [15]. Our data suggest that the nature of the palindromic junction is influenced by 3 '-processing but is not directly related to auto-integration. Indeed, the accumulation of 2-LTRc harboring an imperfect junction in the presence of RAL raises the question related to the relationship between these 2-LTRc forms and the autointegration events since RAL is supposed to inhibit auto-integration. The mechanism behind the formation of these 2-LTRc forms remains to be elucidated.

The observed decreasing phase for circular forms corresponded to dilution due to cell division, in contrast to that observed for integrated forms (Figure 3B). Indeed, the absolute quantities of both 2-LTRc and 1-LTRc significantly decreased (Figures $3 \mathrm{C}$ and E) while their representativeness (normalized by total viral DNA) remained roughly constant (Figures 3D and Figure 3F, respectively). In the case of integrated forms, both their absolute quantity and their representativeness remained constant. A third behavior was observed with linear
DNA: The maximal amount of $\mathrm{DNA}_{\mathrm{L}}$ was obtained $8 \mathrm{~h}$ p.i. coinciding with the maximal amount of total viral DNA originating from reverse transcription (Figure 3G). After $8 \mathrm{~h}$ p.i., the amount of $\mathrm{DNA}_{\mathrm{L}}$ decreased continuously. In contrast to that observed with viral DNA circular forms, the representativeness of $\mathrm{DNA}_{\mathrm{L}}$ also decreased in all conditions of infections (WT+/- RAL and $\mathrm{D} 116 \mathrm{~N})$. This indicates that $\mathrm{DNA}_{\mathrm{L}}$ is less stable than 1-LTRc and 2-LTRc (Figure 3H) (for a detailed analysis of $\mathrm{pDNA}_{\mathrm{L}}$ and $\mathrm{uDNA}_{\mathrm{L}}$ stabilities, see section related to 3 '-processing quantification). Intriguingly, along the decreasing phase characterizing the WT infection, we observed a reproducible rebound of $\mathrm{DNA}_{\mathrm{L}}$ synthesis occurring between 32 and $48 \mathrm{~h}$ p.i., after a significant decreasing phase occurring between 8 and 24 h p.i.. Experiments are ongoing to explain this phenomenon.

Regarding the accumulation of circular DNA forms, it is important to note that impairing integration (RAL treatment or D116N infection) increased the accumulation of 1-LTRc and to a greater extent the accumulation of global 2-LTRc (compare Figures $3 \mathrm{C}$ and E). Accumulations of both 2-LTRc and 1-LTRc were also reflected 
in their relative representativeness (normalized by total viral DNA), but again, with a much more greater relative accumulation for 2-LTRc (10-fold) compared to 1-LTRc (2-fold) (Figures 3D and F). Indeed, in the RAL or D116N context, 2-LTRc reached $15-20 \%$ or $25-27 \%$ of total viral DNA, respectively, compared to $2 \%$ in the standard infection condition (Figure 3D), while 1-LTRc reached $50-60 \%$ of total viral DNA compared to $30 \%$ in the standard infection (Figure 3F). Moreover, our results indicate that the relative representativeness of 1-LTRc and 2-LTRc remained roughly constant from $32 \mathrm{~h}$ p.i. showing that the two circular viral DNA forms are relatively and equally stable.

\section{Two origins for 1-LTRc formation}

As mentioned above, 1-LTRc were detected earlier than 2-LTRc in a context where their respective representativeness were comparable (D116N or WT + RAL) (Figure 3E). This prompted us to re-examine the question of subcellular location for 1-LTRc formation. To date, the origin of 1-LTRc formation remains unclear leading to apparent contradiction in the literature. For instance, Kilzer and colleagues reported that 1-LTRc formation requires homologous recombination between the two LTR of DNA $A_{L}$ which occurs in the nucleus [12]. By contrast, in an early study, Miller and colleagues proposed that 1-LTRc formation involves the reverse transcription step in the cytoplasm compartment [30]. We conducted cell fractionation experiments with MT4 cells 24 h p.i. infected with D116N (when amount of 2-LTRc is maximal; as 2-LTRc are formed exclusively in the nucleus, nuclear import has occurred at this time point [31]). ß-globin and mitochondrial genes quantifications were used as controls for cell fractionation validation (Figure 5A, right panel). Our results demonstrate that 2-LTRc were almost entirely detected in the nuclear fraction (>99.5\%) (Figure 5A, left panel). The 1-LTRc amount was much more higher in the cytoplasmic fraction compared to 2-LTRc. Indeed, in conditions where the nuclear import is maximal, 1-LTRc formed in the cytoplasm represent $10 \%$ of total 1-LTRc (compared to $<0.5 \%$ for 2 -LTRc). This is consistent with the kinetics of 1-LTRc formation where 1-LTRc makes up $10 \%$ of total viral DNA as soon as 5 and $8 \mathrm{~h}$ p.i. (Figure 3E). These observations are compatible with the hypothesis of Miller and collaborators [30] that, at least, some of the 1-LTRc are produced during the reverse transcription step.

Peptides NLS-IN-Pen and SV40-NLS-Pen, previously described to inhibit the PIC nuclear import by inhibiting the Integrase-importin $\alpha$ interaction [32], were used to assess whether 1-LTRc are only formed during the reverse transcription step independently of PIC translocation. The amount of 1-LTRc was then measured and the nuclear import inhibition efficiency was monitored by quantification of 2-LTRc. HeLa cells, treated with either of these peptides, were infected with a pNL4.3 virus in the presence of RAL. In the absence of the peptides, 2-LTRc accumulated to $19.3 \%$ of total viral DNA $48 \mathrm{~h}$ p.i.. Peptide treatments led to an inhibition of 2-LTRc accumulation $(5.22 \%$ and $2.24 \%$ for NLS-IN-Pen and SV40-NLS-Pen, respectively) confirming nuclear import inhibition (3.7 and 8.6 fold for NLS-IN-Pen and SV40NLS-Pen, respectively) (Figure 5B, left panel). Interestingly, in these conditions, we observed a decrease in 1-LTRc formation but not to the same extent compared to 2-LTRc inhibition (1.8 and 2.5 fold for NLS-INPen and SV40-NLS-Pen, respectively) (Figure 5B, right panel). It has been reported that inhibition of the PIC nuclear import can also be prevented more specifically by mutation in the FLAP and/or CTS region of the virus $[23,33]$. We infected HeLa cells with a defective mutant, affected in both the CTS and the PPT, and assayed 2-LTRc and 1-LTRc (relative to the WT condition) $24 \mathrm{~h}$ p.i. (Figure 5C). Disruption of the FLAP structure partially inhibited PIC nuclear import (and not fully as described in [23]), and was associated with the amount of 2-LTRc being reproducibly and significantly less than for the WT (about 2-fold). Such a decrease is compatible with previous findings indicating that mutants affected in the FLAP structure may replicate albeit slower than the WT [34-36]. In this context, we found a concomitant decrease of 1-LTRc but to a lesser extent (1.4-fold). Taken together, these data clearly suggest that the two mechanisms of 1-LTRc formation (and the two associated subcellular localizations) are not mutually exclusive: 1-LTRc can be formed in the cytoplasm during the reverse transcription step as previously suggested [30] but that most 1-LTRc (90\%) is formed by homologous recombination after PIC translocation in the nucleus [12].

Time course of the 3 '-processing reaction in infected cells and study of the differential stability of 3'-processed and blunt linear viral DNAs

Regarding $\mathrm{DNA}_{\mathrm{L}}$ quantification, the ability of our PCRbased protocol to further discriminate between both $\mathrm{pDNA}_{\mathrm{L}}$ and $\mathrm{uDNA} \mathrm{L}_{\mathrm{L}}$ forms, prompted us to study the kinetics of the 3 '-processing reaction directly in infected cells. We used several conditions of infection: WT (permissive for both 3 '-processing and integration processes), WT + RAL (permissive for 3 '-processing reaction only, according to in vitro assays [37]) or D116N context (non permissive for both processes). At this stage, it is important to note that our protocol for quantifying total $\mathrm{DNA}_{\mathrm{L}}, \mathrm{pDNA}_{\mathrm{L}}$ and $\mathrm{uDNA}_{\mathrm{L}}$ was validated using the LTR-5' of the virus. We performed similar quantifications using specific primers and probes for the LTR-3' (see Methods). The quantification of both 

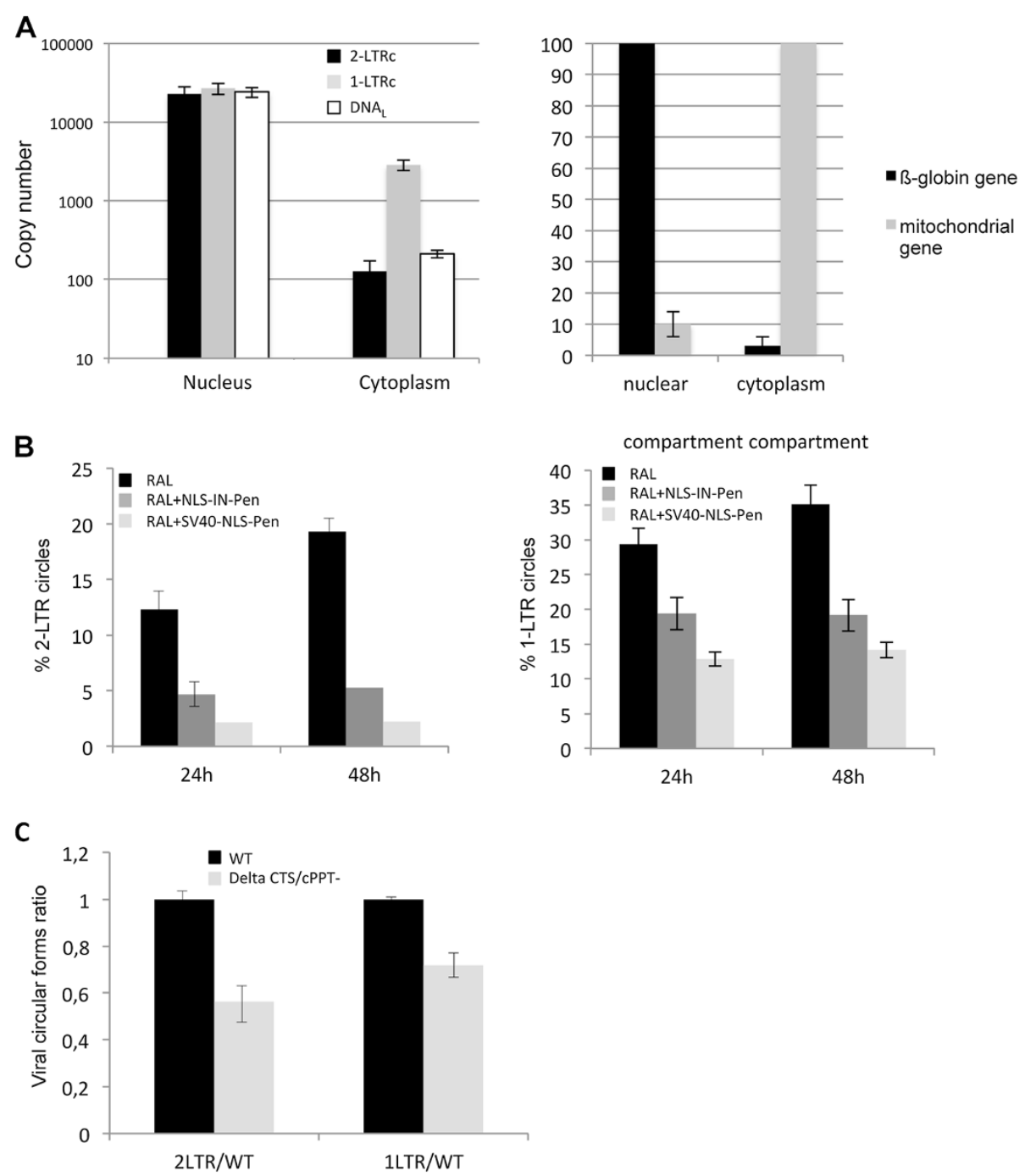

Figure 5 Localization of 1-LTRc formation. (A) Left panel, HeLa cells were infected cells with NLENG1-ES-IRES D116N and fractionated into a cytoplasmic and nuclear fraction $24 \mathrm{~h}$ post-infection. 2-LTRc (black columns), 1-LTRc (grey columns) and DNAL (white columns) were quantified in each fraction. Right panel, quantification of ß-globin gene and mitochondrial gene in the nuclear and cytoplasmic compartment. (B) HeLa cells were infected (WT + $500 \mathrm{nM}$ RAL; black columns) in the presence of either $100 \mu \mathrm{M}$ NLS-IN-Pen (dark grey columns) or $100 \mu \mathrm{M}$ SV40-NLS-Pen (grey columns). Percentages of 2-LTRc (left panel) and 1-LTRC (right panel) at two times post-infection are shown. (C) HeLa cells were infected either with pNL4.3 virus (WT; black columns) or the CTS/CPPT mutant virus (grey columns). Ratios of 2-LTRC and 1-LTRc (the amount of 2-LTRC or 1-LTRc in the mutant condition divided by that for the WT at $24 \mathrm{~h}$ post-infection) are shown. Each value corresponds to an average of five to six independent experiments and confidence intervals analysis are shown for a $p$ value $<0.05$.

$\mathrm{pDNA}_{\mathrm{L}}$ and $\mathrm{uDNA}_{\mathrm{L}}$ in infected MT4 cells led to similar values for $3^{\prime}$-processing activity at both LTR-3' and LTR-5' ends (Additional file 1: Figure S3), consistent with a previous report [38]. In the following study, $\mathrm{pDNA}_{\mathrm{L}}$ and $\mathrm{UDNA} \mathrm{L}_{\mathrm{L}}$ were then quantified on the LTR-5'.

Both the D116N mutation and RAL treatment prevent integration; however, only $\mathrm{D} 116 \mathrm{~N}$ is expected to prevent the $\mathrm{pDNA}_{\mathrm{L}}$ formation [7,39]. Indeed, RAL, like other strand transfer inhibitors, is relatively ineffective against the 3 '-processing reaction. Accordingly, no significant amount of $\mathrm{pDNA}_{\mathrm{L}}$ was detected with D116N (Figure 6C). In contrast, there was no significant difference between the 3 '-processing activity for WT + RAL (500 nM) and WT without RAL (Figure 6A and Figure 6B, respectively). Moreover, the 3 '-processing reaction was concomitant with reverse transcription as the maximum amounts of both linear viral DNA (Figure 3G) and pDNA $_{\mathrm{L}}$ (Figure $6 \mathrm{~A}$ ) were found at $8 \mathrm{~h}$ p.i.. The reaction yield for the 3 '-processing reaction was high (more than $80 \%$ of $\mathrm{DNA}_{\mathrm{L}}$ was processed at $8 \mathrm{~h}$ p.i.) and corresponds to a fast reaction as the times characterizing the maximum amounts of total linear viral DNA and $\mathrm{pDNA}_{\mathrm{L}}$ coincide according to Miller's study [40]. The $\mathrm{pDNA}_{\mathrm{L}}$ : $\left(\mathrm{pDNA}_{\mathrm{L}}+\mathrm{uDNA} \mathrm{L}_{\mathrm{L}}\right)$ ratio decreased with time after $8 \mathrm{~h}$ 


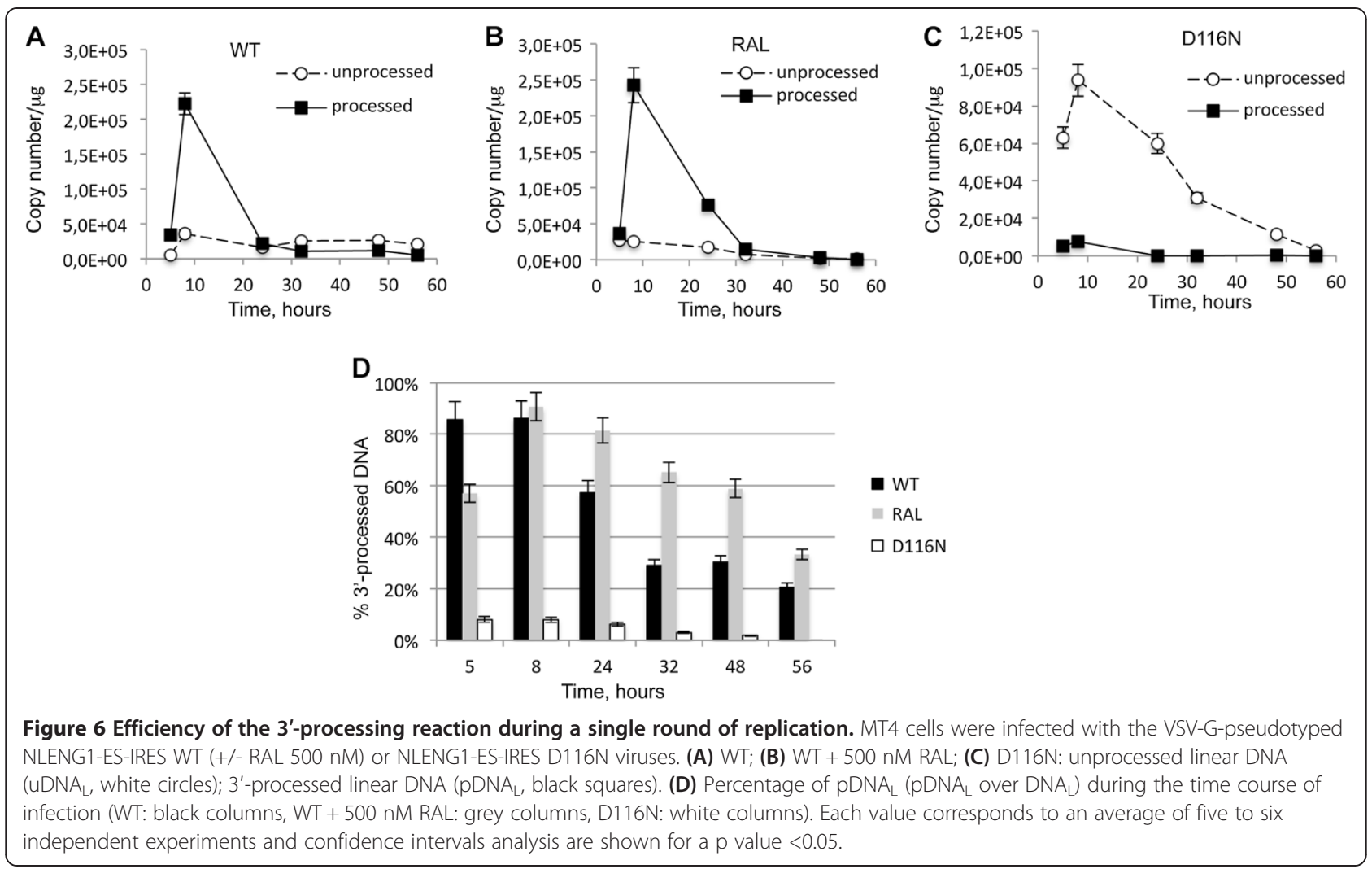

p.i. in all experimental conditions (WT+/-RAL) indicating that $\mathrm{pDNA}_{\mathrm{L}}$ was less stable than $\mathrm{uDNA}_{\mathrm{L}}$ (Figure $6 \mathrm{D}$ ). For each time point along the decreasing phase, this ratio was consistently lower in the absence of RAL than presence of RAL. Such a difference most likely accounts for integration events that occur in the absence of RAL.

\section{Differential inhibition of the 3'-processing reaction by RAL, EVG and DTG}

Two other strand-transfer inhibitors, DTG and EVG $[41,42]$, were studied for their ability to inhibit the 3 'processing reaction and were systematically compared to RAL. The three drugs display similar $\mathrm{IC}_{50}$ for the integration inhibition during viral infection: $2 \mathrm{nM}$ for DTG and EVG and $8 \mathrm{nM}$ for RAL (Additional file 1: Figure S4A). Quantitative PCR was used to assay pDNA and $\mathrm{UDNA}_{\mathrm{L}}$ as described above. At the lowest concentration (500 nM) of RAL, DTG or EVG, which fully inhibits viral integration, the 3 '-processing step was not significantly impaired (Figure 7A, upper panel). Interestingly, the three drugs at higher concentrations had different effects on the 3 '-processing reaction (Figure 7B-C, upper panels). Indeed, RAL at concentrations up to $5 \mu \mathrm{M}$ did not effectively inhibit 3 ' -processing (3'-processing efficiency was still $80 \%$ at $5 \mu \mathrm{M}$ RAL). By contrast, $3^{\prime}$-processing was greatly impaired using 2.5 or $5 \mu \mathrm{M}$ of DTG and EVG (3'-processing efficiencies were about $40 \%$ and below $25 \%$ at $2.5 \mu \mathrm{M}$ and $5 \mu \mathrm{M}$, respectively). Accordingly, in vitro studies, using recombinant integrase, demonstrate that the three integrase inhibitors do not inhibit the $3^{\prime}$-processing reaction to the same extent (Additional file 1: Figure $\mathrm{S} 4 \mathrm{~B}$ ). $\mathrm{IC}_{50}$ values for 3 '-processing inhibition were $2 \mu \mathrm{M}, 5 \mu \mathrm{M}$ and $10 \mu \mathrm{M}$ for DTG, EVG and RAL, respectively according to Metifiot et al. study for RAL and EVG [43]. The differential effects of the three compounds on the 3 '-processing reaction were confirmed using a radiolabeled probe produced by PCR (as described in the online methods section) (Additional file 1: Figure S4C). As shown in Figure 7, the presence of $500 \mathrm{nM}$ of any of RAL, DTG and EVG led to similar amounts of 3'-processed DNA whereas, at $5 \mu \mathrm{M}$, DTG and EVG significantly inhibited 3'-processing, in contrast to that observed for RAL.

Interestingly, increasing the DTG or EVG concentration, from $500 \mathrm{nM}$ to $5 \mu \mathrm{M}$, progressively increased the inhibition of $3^{\prime}$-processing but did not lead to a greater accumulation of 2-LTRc (Figure 7A-C, middle and lower panels). Indeed, across this concentration range where DTG and EVG equally (and fully) inhibit integration while 3'-processing inhibition is concentration dependent. 2-LTRc consistently represent nearly $40 \%$ of the total viral DNA $48 \mathrm{~h}$ p.i.. Such a comparable global accumulation of 2-LTRc, regardless of the 3'-processing efficiency, could be explained as above-mentioned by a 


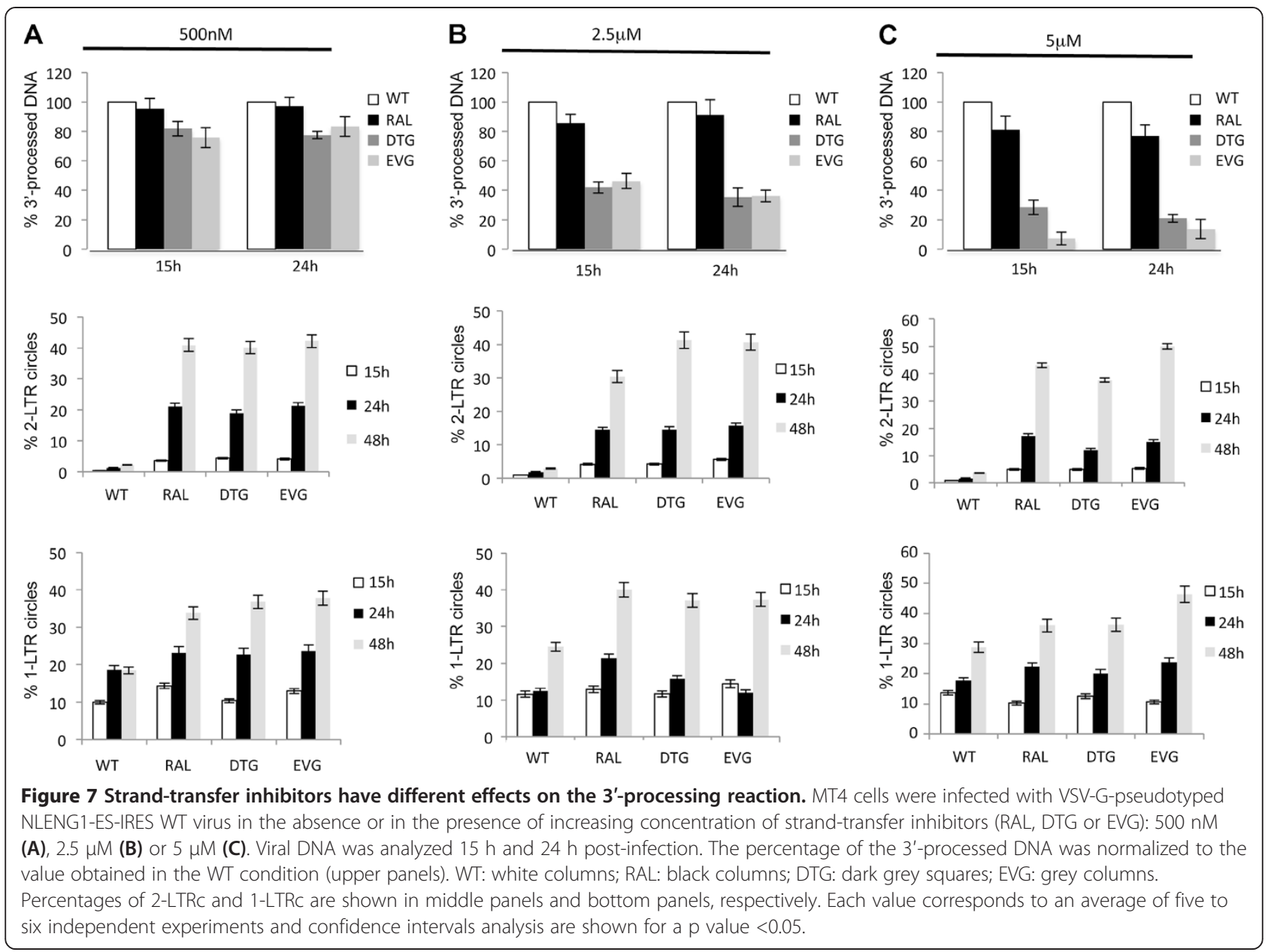

different proportion of 2-LTRc harboring perfect/imperfect junction which is modulated by the 3 '-processing efficiency (see Figure 4). All together, our data show that, at submicromolar concentration, INSTIs behave similarly in the virological context and in vitro (i.e. they are specific inhibitors of the strand-transfer reaction and have little effect on the 3 '-processing reaction), and that the 3 '-processing reaction influences the nature of 2-LTRc qualitatively but not quantitatively. We also measured 3'-processing efficiency during infection of primary $\mathrm{CD} 4+\mathrm{T}$ cells with the previously described viruses $\Delta$ env WT $(+/-5 \mu \mathrm{M}$ RAL, EVG or DTG). As described previously during MT4 infection, 3 '-processing reaction efficiency was high (75\%) but slightly delayed in primary cells (3'-processing reaction peaked 24 h p.i.) and was influenced by $5 \mu \mathrm{M}$ EVG and DTG but not RAL, as previously found in MT4 cells (Additional file 1: Figure S5). Furthermore, the kinetics of 2-LTRc and 1-LTRc were similar in primary cells and in MT4 infections (Additional file 1: Figure S5, middle and right panels).

\section{Discussion}

Methods are available to quantify accurately various HIV-1 viral DNA forms including total viral DNA, 2LTRc and integrated viral DNA [18]. However, no methodology had been developed for assaying 1-LTRc in a sensitive manner. It has even been suggested that PCRbased methods are unable to quantify 1-LTRc [20]. Amplification with primers spanning the LTR leads to unspecific amplification from both $\mathrm{DNA}_{\mathrm{L}}$ and 2-LTRc. The appropriate application of one crucial parameter (elongation time) explains why our methodology is accurate for 1-LTRc quantification. We found empirically that an elongation time of $25 \mathrm{~s}$ was optimal for efficient and specific amplification of 1-LTRc. A shorter elongation time (18 s) was associated with a lower amplification efficiency whereas a longer elongation time (32 s) resulted in unspecific amplification from DNA mimicking $\mathrm{DNA}_{\mathrm{L}}$ (Additional file 1: Figure S2). For example, amplification of 200,000 copies of $\mathrm{DNA}_{\mathrm{L}}$ (as quantified by primers and probes used for total viral DNA quantification) using our 1-LTRc protocol, but with 
an elongation time of $32 \mathrm{~s}$, led to nearly 87,000 copies corresponding to $43 \%$ of unspecific amplification (Additional file 1: Figure S2, right table). Our results, sustained by those obtained by Yoder and colleagues, indicate that increasing elongation time leads to unspecific amplification and particularly from $\mathrm{DNA}_{\mathrm{L}}$. The elongation time used by Yoder and colleagues was even longer (60s), and not compatible with a reliable quantification of 1-LTRc [20]. Concerning $\mathrm{DNA}_{\mathrm{L}}$, the number of cycles in the first PCR (12 cycles) was determinant for reliable quantification. We compared the sensitivity of our method to that of Southern blotting: the sensitivity of our quantitative PCR was $10^{2}$ copies $/ 10^{6}$ cells, whereas that of Southern blotting was $10^{5}$ copies $/ 10^{6}$ cells.

We used these methods to determine the amounts of 1-LTRc and $\mathrm{DNA}_{\mathrm{L}}$ in its two forms (3' -processed DNA $\left(\mathrm{pDNA}_{\mathrm{L}}\right)$ or unprocessed $\left(\mathrm{uDNA}_{\mathrm{L}}\right)$ ) in several conditions of infections. The findings of these analyses contribute to understanding various unresolved issues (i) the precise timing, efficiency and localization of the processing step required for the proper integration of viral DNA (ii) the relative lifetimes of $\mathrm{DNA}_{\mathrm{L}}$ and circular viral forms (iii) the mechanism of action of anti-integrase compounds during infection (i.e. inhibitors of 3'-processing only, inhibitors of strand-transfer only or inhibitors of both reactions) and (iv) the localization of the formation of circular viral DNA forms.

\section{Characterization of linear viral DNA forms}

Regarding the quantification of $\mathrm{DNA}_{\mathrm{L}}$, our quantitative PCR-based methodology allows to discriminate between $\mathrm{uDNA}_{\mathrm{L}}$ and $\mathrm{pDNA}_{\mathrm{L}}$. We showed that the 3 '-processing reaction corresponds to an early event that is concomitant with the reverse transcription step, evidence that 3 '-processing occurs in the cytoplasmic compartment. In both MT4 cell line and primary CD $4+\mathrm{T}$ cells, $85 \%$ of the $\mathrm{DNA}_{\mathrm{L}}$ is 3 '-processed (Figure 6D) indicating that 3 ' processing in the wild-type context is efficient. Given this high reaction efficiency, it is unlikely that 3 '-processing is the limiting factor for integration (40\% of the total viral DNA is integrated (Figure 3B)). The relatively low integration yield may be a consequence of the formation of circular forms, poor stability of $\mathrm{pDNA}_{\mathrm{L}}$ (see below) or inefficiency of the strand transfer reaction.

We found the following order for the stability of the viral DNA forms: integrated DNA > circular DNA (1-LTRc and 2-LTRc) $>\mathrm{uDNA}_{\mathrm{L}}>\mathrm{pDNA}_{\mathrm{L}}$. Integrated DNA is the most stable form due to its replication with cellular DNA, whereas circular forms are diluted by cell division. The loss of $\mathrm{DNA}_{\mathrm{L}}$ is believed to be the consequence of several phenomena: integration of $\mathrm{pDNA}_{\mathrm{L}}$, degradation of viral extremities by cellular proteins and circularization of $\mathrm{DNA}_{\mathrm{L}}$ [44-46]. Additionally, we found that the lifetime of $\mathrm{pDNA}_{\mathrm{L}}$ was shorter compared to $\mathrm{UDNA}_{\mathrm{L}}$ and therefore that $\mathrm{pDNA}_{\mathrm{L}}$ is intrinsically less stable than $\mathrm{uDNA}_{\mathrm{L}}$. Indeed, in the absence of RAL, $\mathrm{pDNA}_{\mathrm{L}}$ is integrated into the host cell genome, explaining, at least in part, its disappearance. However, even in the presence of RAL such that no $\mathrm{pDNA}_{\mathrm{L}}$ is integrated, $\mathrm{pDNA}_{\mathrm{L}}$ remains less stable than $\mathrm{uDNA}_{\mathrm{L}}$. The relative instability of $\mathrm{pDNA}_{\mathrm{L}}$ in this condition is probably due to a conformational modification of IN after 3 '-processing resulting in a lower stability of IN itself on the viral DNA end. In the absence of any integration event, IN can dissociate from the LTR ends leading to degradation of the LTR ends.

Nanomolar concentrations of RAL, DTG and EVG efficiently inhibit the integration process $[47,48]$. We found that, although RAL, DTG and EVG in the micromolar range inhibit 3 '-processing to different extents both in vitro and in the virological context, none of these compounds inhibit $3^{\prime}$-processing in infected cells at submicromolar concentrations that fully inhibit integration (e.g. $500 \mathrm{nM}$ ). This demonstrates that RAL, DTG and EVG are primarily INSTI compounds in the virological context. As $\mathrm{uDNA}_{\mathrm{L}}$ is more stable than $\mathrm{pDNA}_{\mathrm{L}}$, it is important to know the performance of anti-IN inhibitors, with clinical potential, against 3 '-processing in the virological context. Indeed, compounds which, in the same concentration range, inhibit both integration and 3 '-processing reactions, may favor accumulation of $\mathrm{uDNA}_{\mathrm{L}}$ relative to $\mathrm{pDNA}_{\mathrm{L}}$ (due to 3 '-processing inhibition). Due to the greater stability of $\mathrm{uDNA}_{\mathrm{L}}$, this could be a risk factor for viral resumption.

\section{Formation of circular viral DNA forms}

It has been clearly demonstrated that 2-LTRc are formed in the nucleus of infected cells [49], and we confirmed this result (Figure 5). The situation is less clear for 1-LTRc. Indeed, a significant amount of 1-LTRc (10\% of total 1-LTRc) was detected in the cytoplasmic fraction, consistent with 1-LTRc formation being linked to reverse transcription as early suggested by Miller and colleagues [30]. However, we found that $90 \%$ of the 1-LTRc was in the nuclear compartment, and that the total mount of 1-LTRc was reduced when nuclear import was impaired (using peptides inhibiting the integraseimportin $\alpha$ or a PPT/CTS mutant). Therefore, most of 1LTRc are generated in the nucleus. Thus, our results reconciles apparent contradictions in the literature and indicate that there are two mechanisms of 1-LTRc formation co-exist in infected cells, whereas 2-LTRc are exclusively formed in the nucleus.

We also observed that the overall amount of 2-LTRc accumulation (including both of 2-LTRc: the first subgroup encompassing a perfect palindromic junction and the second harboring an imperfect palindromic junction) 
was not directly related to the 3 '-processing reaction: increasing EVG or DTG concentrations from $500 \mathrm{nM}$ to $5 \mu \mathrm{M}$, and thereby modulating the 3 '-processing reaction yield, did not affect the 2-LTRc accumulation. This confirms previous studies reporting that amount of 2-LTRc was the same after RAL treatment (believed not to inhibit 3 '-processing) or infection with the D116N mutant (3'-processing is inhibited) [29,50]. This result is somewhat surprising since, due to the incompatibility of the 3 '-processed ends with circularization of $\mathrm{DNA}_{\mathrm{L}}$, the amount of 2-LTRc would be expected to be impaired. However, we found that 500 nM RAL did not inhibit 3'processing in the virological context or in vitro, and that RAL treatment and D116N did not led to accumulation of the two 2-LTRc subgroups to the same extent. Following RAL treatment, about $50 \%$ of 2 -LTRc have a perfect palindromic junction, as in the case in control WT conditions, whereas in the D116N condition $80 \%$ of the 2-LTRc have a perfect palindromic junction (Figure 4). In conclusion, 3 '-processing efficiency does not influence the total amount of 2-LTRc but affects the nature of the palindromic junction in the 2-LTRc (perfect versus imperfect junctions).

\section{Conclusions}

Our methods allowing accurate quantification of 1-LTRc and $\mathrm{DNA}_{\mathrm{L}}$ have provided important information about the fate of the various viral DNA forms (integrated viral DNA, 2-LTRc, 1-LTRc and DNA $\mathrm{L}_{\mathrm{L}}$ ) during viral infection and could be applied to study the lifetime of circular and linear DNA in patients. Other viral DNA forms originating from auto-integration exist. As underlined by Yan et al., it is a hard task to quantify these viral DNA forms due to their heterogeneous nature [15]. However, these forms appear to be not highly represented relative to the total viral DNA. Indeed, our data show that the amount of total viral DNA is similar to the addition of integrated, 1-LTRc, 2-LTRc and $\mathrm{DNA}_{\mathrm{L}}$ amounts. These methods can be used to follow the fate of viral DNA forms, the distributions of which may be influenced by mutations or inhibitors of HIV-1 viral proteins. Indeed, the quantification of 3 '-processed DNA in infected cells may help to elucidate, directly in the cell context, the mechanism of integrase inhibitors developed for clinical applications.

\section{Methods}

\section{Cells and viruses}

MT4 and Nalm6/Nalm114 cells were cultured in RPMI1640. The ligase 4 gene was knockout from the parental cell line Nalm-6 to obtain Nalm-114 cells. Ligase 4 is a component of the NHEJ (Non-Homologous End Joining) pathway involved in 2-LTRc formation [12]. HeLa and $293 \mathrm{~T}$ cells were cultured in DMEM. Both mediums were supplemented with $10 \%$ fetal calf serum. HIV-1 pNL4.3 stocks were prepared by transfecting 293 T with the HIV-1 molecular clone pNL4.3 or with HIV-1 molecular clones derived from the pNL4-3 ( $\Delta$ env viruses) [26]. $\triangle$ env viruses NLENG1-ES-IRES WT and NLENG1-ES-IRES D116N encode the WT and catalytically inactive mutant D116N, respectively. Pseudotyping of $\Delta$ env viruses was performed by co-transfection of 293 T cells with a VSV-G plasmid using the calcium phosphate method. Viral supernatants were filtered $(0.45 \mu \mathrm{m})$ and frozen at $-80^{\circ} \mathrm{C}$.

\section{Isolation of highly purified CD4 $+\mathrm{T}$ cells}

Highly purified CD4 + T cells were isolated from peripheral blood mononuclear cells (PBMC) of HIV-1 negative donors from EFS (Etablissement Français du Sang). Briefly, PBMC were obtained by centrifugation on FicollHypaque gradient. Purification of CD4+ T cells was achieved by staining cells with CD4 MicroBeads (MACS ${ }^{\odot}$, Miltenyi Biotec) and purified with the Whole Blood Column Kit (MACS ${ }^{\ominus}$, Miltenyi Biotec). Purified CD4 + T cells were cultured in RPMI1640 supplemented with 2\% Human serum, penicillin-streptomicine, and in presence of IL-2 (50 ng/ml). CD $4+\mathrm{T}$ cells were activated with phytohemagglutinin (PHA, $2.5 \mu \mathrm{g} / \mathrm{ml}$ ) during 3 days and were used for experiments 7 days after the activation treatment.

\section{Viral infection}

HIV-1 p24 ${ }^{\text {gag }}$ antigen contents in viral inocula were determined by enzyme-linked immunosorbent assay (Perkin-Elmer Life Sciences). For the WT, $120 \mathrm{ng}$ of p $24^{\text {gag }}$ antigen per $10^{6}$ cells, corresponding to a multiplicity of infection (m.o.i.) of 0.3, was used for infection. Primary CD $4+\mathrm{T}$ cells were infected with $100 \mathrm{ng}$ of p24 gag antigen per $10^{6}$ cells. When required, cells were treated in the presence of several integrase inhibitors such as RAL, DTG and EVG at $500 \mathrm{nM}, 2.5 \mu \mathrm{M}$ or $5 \mu \mathrm{M}$. Two to five millions cells were collected at each time point. Cells were washed in PBS, and dry cell pellets were frozen at $-80^{\circ} \mathrm{C}$ until use. DNA from infected cells was purified with QIAamp DNA Blood mini kit (Qiagen) according to the manufacturer's instructions. To digest residual transfection plasmid, DNA was incubated with 10 units of DpnI (NEB) according to the manufacturer's instructions for 4 hours at $37^{\circ} \mathrm{C}$.

\section{Plasmids}

Four plasmids were constructed for standard curves amplification: p1-LTR, p2-LTR, pLIN-HIV-ScaI and pLINHIV-NdeI.

pLIN-HIV-ScaI plasmid was constructed using a linkermediated PCR (LM-PCR). MT4 cells were infected with pNL4.3 HIV-1 and DNA was extracted. The three terminal 
nucleotides of HIV-1 DNA LTR represent a half of the ScaI restriction site. Viral DNA was ligated with a linker composed of oligonucleotides 25SCAt ( $5^{\prime}$-GC GGTGACCCGGGAGATCTGAATTCAGT-3') and 11SCAb (5'-ACTGAATTCAGATCTCCCGG-3'), containing the complementary moiety of ScaI site. The ligation product was next used to amplify the termini of linear viral genome linked with the linker by PCR using primers $25 \mathrm{t}$ and MS1 (see Additional file 1: Table S1B). PCR was performed as follows: $95^{\circ} \mathrm{C} / 30 \mathrm{sec}, 55^{\circ} \mathrm{C} / 30 \mathrm{sec}$ and $68^{\circ} \mathrm{C} / 1 \mathrm{mn}$ for 35 cycles. The reaction product was purified on agarose gel, cloned into the pGEM-T easy vectors (Promega) and sequenced. Note that the ScaI site in the pGEM-T easy vector was removed by site directed mutagenesis (QuikChange Lightning Kits, Agilent). Site directed mutagenesis (QuikChange Lightning Kits, Agilent) was also performed on this plasmid to remove the ScaI recognition site in position 314 in the LTR5' with primers 5' ${ }^{\prime}$-CCCGAGAGCTGCATCCGGA GAACTACAAAGACTGCTGACATCG-3' and 5'-CGA TGTCAGCAGTCTTTGTAGTTCTCCGGATGCAGCTC TCGGG-3'. The final plasmid, pLIN-HIV-ScaI, contains only one ScaI site at the bounder of the linker and LTR5' extremity. Digestion with ScaI and AatII leads to a fragment mimicking the extremity (LTR5') of unprocessed viral DNA end. After purification, this fragment was used for ligation reaction with linker $11 \mathrm{~b}$ in order to quantify unprocessed linear DNA $\left(\mathrm{uDNA}_{\mathrm{L}}\right)$.

pLIN-HIV-NdeI was constructed by site directed mutagenesis (QuikChange Lightning Kits, Agilent) to replace the ScaI site by NdeI site at the linker-viral DNA junction, using primers 5'-CCGGGAGATCTGAATTC AGTCATATGGAAGGGCTAATTTGGTCC-3' and 5' GGACCAAA TTAGCCCTTCCATATGACTGAATTCA GATCTCCCGG-3'. The digestion with NdeI and AatII leads to a fragment mimicking the extremity of the 3'processed viral DNA. After purification, this fragment was used for ligation reaction with linker 11TAb.

p1-LTR was obtained by amplification, from HIV-1 infected cells DNA, of the env-LTR-gag region, specifically present on 1-LTRc, using primers 1LTR LA1 and 1LTR LA16 (see Additional file 1: Table S1B). This amplification product was cloned into the pGEMT-easy vector (Promega) to give p1-LTR.

p2-LTR was constructed in two steps as follows: pLINHIV-ScaI-LTR3' was first constructed by the same methodology described for pLIN-HIV-ScaI. Primers used for LM-PCR were $25 \mathrm{t}$ and 1LTR LA16 (see Additional file 1: Table S1B), resulting in amplification of the envLTR3' region. The Scal recognition site present in the LTR3' of pLIN-HIV-ScaI-LTR3' was mutated (as previously done for the ScaI site in the LTR5' of pLIN-HIVScaI) by site directed mutagenesis (QuikChange Lightning Kits, Agilent) using primers 5'-AGCTGCATCCGGAGCA
CTTCAAGAACTGCT-3' and 5'-AGCAGTTCTTGAA GTGCTCCGGATGCAGCT-3'. The two plasmids, pLINHIV-ScaI and pLIN-HIV-ScaI-LTR3', were digested by ScaI, and fragments containing respectively the env-LTR3' and the gag-LTR5' regions were purified on agarose gel and ligated together into the pGEMT-easy vector (Promega) to give p-2LTR.

\section{Quantification of total linear DNA (DNA $\left.A_{L}\right)$, unprocessed ( $u D N A_{L}$ ) and 3'-processed $\left(p D N A_{L}\right.$ ) linear forms by $L M-P C R$ Principle}

$\mathrm{DNA}_{\mathrm{L}}$ quantification was performed by a linker-mediated PCR approach (LM-PCR). The choice of the linkers was based on the early study by Pierson and colleagues [22]. In order to quantify either the total amount of linear DNA $\left(\mathrm{DNA}_{\mathrm{L}}\right)$-which comprises both the unprocessed $\left(\mathrm{uDNA}_{\mathrm{L}}\right)$ and the $3{ }^{\prime}$-processed $\left(\mathrm{pDNA}_{\mathrm{L}}\right)$ - or, more specifically, the $\mathrm{uDNA}_{\mathrm{L}}$ only, we used the linkers $11 \mathrm{TAb}$ and $11 \mathrm{~b}$, respectively, for establishing standard calibration (Additional file 1: Table S1A). Two rounds of PCR were performed using primers and probes described in Additional file 1: Table S1B; the number of rounds of the first PCR was critical for further quantitative analysis and we found that 12 cycles correspond to the optimal condition for the two linkers (Additional file 1: Figure S6).

\section{Method}

Quantifications were performed by real-time PCR on a Light cycler instrument (Roche Diagnostics) using the second-derivative-maximum method provided by the Light Cycler quantification software, version 3.5 (Roche Diagnostics). Two linkers: Linker $11 \mathrm{~b}$ and 11TAb (or $11 \mathrm{GTb}$ in the virological context; see below) (see Additional file 1: Table S1A) were used for the quantification of $\mathrm{uDNA}_{\mathrm{L}}$ and $\mathrm{pDNA}_{\mathrm{L}}$, respectively. These linkers were assembled by annealing two partially complementary unphosphorylated oligonucleotides (to give $34 \mathrm{nM}$ ) final concentration) in the presence of $200 \mathrm{mM} \mathrm{NaCl}$. To quantify linear forms of HIV-1 DNA, a ligation reaction mixture was carried out by addition of linkers (final concentration: $30 \mathrm{nM}$ ) to DNA, in the presence of 10 units of ligase from the Quick ligation kit (NEB), for 2 hours at room temperature in a final volume of $20 \mu \mathrm{L}$, according to the manufacturer's instructions. Linked DNA products were then purified with PCR switch charge purification kits (Life Technology) according to the manufacturer's instructions (to prevent inhibition of the PCR due to the mixture of ligation reaction) and eluted in $20 \mu \mathrm{L}$ and then submitted to real-time PCR. In a first round of PCR, 1/10 of DNA was amplified in duplicate in a $20 \mu \mathrm{l}$ reaction mixture comprising $1 \times$ LightCycler FastStart DNA master Hybprobes (Roche), $4 \mathrm{mM} \mathrm{MgCl}_{2}, 32 \mathrm{t}$ and MS1 primers (300nM) for 
quantification of the LTR5' (Additional file 1: Table S1B) or $32 \mathrm{t}$ and 1LTR LA15 (5'- CACACCTCAGGTA CCTTTAAGA-3') (300 nM) for LTR3'. To remain in the exponential phase allowing quantitative properties of the second PCR, 12 cycles are required for the first PCR. Decreasing the number of cycles for the first PCR leads a non-reproducibility in the samples quantifications (Additional file 1: Figure S6). Increasing the number of cycles for the first PCR results in a false quantification because the exponential phase allowing quantitative properties of the second PCR is not respected (Additional file 1: Figure S6). 12 cycles are sufficient to ensure quantitative conditions for all linked-DNA dilutions for the second PCR. The second PCR was performed on $1 / 100$ of the first PCR-product in a mixture comprising $1 \times$ LightCycler FastStart DNA master Hybprobes, $4 \mathrm{mM} \mathrm{MgCl} 2,25 \mathrm{t}$ and MS2 primers (300 nM) and hybridization probes $\mathrm{MH}$ FL and MH LC (200 nM) for quantification of the LTR5' (Additional file 1: Table S1B) or $25 \mathrm{t}$ and 1LTRnested (5' - GCTAATTCACTCCCAACGAAG-3') (300 nM) and hybridization probes LTR FL and LTR LC (200 nM) (Additional file 1: Table S1B) for LTR3'. Efficiency of the $\mathrm{uDNA}_{\mathrm{L}}$ quantification was determined by addition of the linker $11 \mathrm{~b}$ to serial dilutions of the fragment from the digestion of pLIN-HIV-ScaI with ScaI and AatII. For $\mathrm{pDNA}_{\mathrm{L}}$ quantification, the efficiency of the procedure was determined by addition of the linker 11TAb (composed of oligonucleotides $25 \mathrm{t}$ and 11TAb) (see Additional file 1: Table S1A) to serial dilutions of the fragment obtained after digestion of pLIN-HIV-NdeI with NdeI and AatII. $11 \mathrm{GTb}$ characterization as well as comparison between Southern blot and quantitative PCR were shown in Additional file 1: Figure S1).

\section{Method validation}

To assess both the sensitivity and the linear range of amplification, we used DNA mimicking the $\mathrm{uDNA}_{\mathrm{L}}$ or $\mathrm{pDNA}_{\mathrm{L}}$ (obtained by ScaI/AatII or NdeI/AatII digestion of pLIN-HIV-ScaI or pLIN-HIV-NdeI, respectively (Figure $1 \mathrm{~A})$ ). $\mathrm{uDNA}_{\mathrm{L}}$ or $\mathrm{pDNA}_{\mathrm{L}}$ were quantified independently using total viral DNA quantification protocol (line 1, Additional file 1: Table S1B). The standard curves were monitored by serial dilutions of the fragments mimicking $\mathrm{uDNA}_{\mathrm{L}}$ or $\mathrm{pDNA}_{\mathrm{L}}$ in $\mathrm{DNA}$ of uninfected cells. Linkers $11 \mathrm{TAb}$ or $11 \mathrm{~b}$ were used for ligation of each dilutions of viral DNA extremity $\left(\mathrm{uDNA}_{\mathrm{L}}\right.$ or $\mathrm{pDNA}_{\mathrm{L}}$ ). After ligation and DNA purification, 1/10 of the ligation reaction was submitted to real-time PCR (12 cycles as above-mentioned). It is important to note that quantifications of samples account for the ligation efficiency. Amplified products were diluted (1/10) and next submitted to the second PCR round. Efficiencies and sensitivities related to $\mathrm{uDNA}_{\mathrm{L}}$ and $\mathrm{pDNA}_{\mathrm{L}}$ quantification were identical ( $90 \%$ efficiency on a $7-\log$ range; sensitivity of 10 copies for 200,000 cells) (Figure 1B). To assess the specificity of the quantification procedure, we tested the detection efficiency of $\mathrm{pDNA}_{\mathrm{L}}$ or $\mathrm{uDNA} \mathrm{A}_{\mathrm{L}}$ when using either $11 \mathrm{TAb}$ or $11 \mathrm{~b}$ linker (Figure $1 \mathrm{C}$ ). We confirmed qualitative results from Pierson [22], i.e. 11TAb was not able to discriminate between $\mathrm{pDNA}_{\mathrm{L}}$ and $\mathrm{uDNA} \mathrm{L}_{\mathrm{L}}$, while $11 b$ led to detection of $\mathrm{uDNA}_{\mathrm{L}}$ only. From a quantitative point of view, the detection efficiency of $\mathrm{pDNA}_{\mathrm{L}}$ and $\mathrm{uDNA}_{\mathrm{L}}$ by LM-PCR using 11TAb as a linker was identical and high (90\%) (Figures $1 \mathrm{~B}$ and Figure 1C). The LM-PCR with linker $11 \mathrm{~b}$ allows a high degree of selectivity in the detection, with detection efficiencies of $95 \%$ and $3 \%$ for $\mathrm{uDNA}_{\mathrm{L}}$ and $\mathrm{pDNA}_{\mathrm{L}}$, respectively (Figure 1C). Performing two independent experiments (each one with a different linker), accurate quantifications of the total amount of $\mathrm{DNA}_{\mathrm{L}}$ and the amount of $\mathrm{UDNA}_{\mathrm{L}}$ are thus possible. The $\mathrm{pDNA}_{\mathrm{L}}$ amount can be then simply deduced by subtraction: total $\mathrm{DNA}_{\mathrm{L}}$ (using 11TAb) minus $\mathrm{uDNA}_{\mathrm{L}}$ (using 11b). The ability of the linker $11 \mathrm{TAb}$ to detect $\mathrm{uDNA}_{\mathrm{L}}$ could be due to the fact that the overhanging nucleotides of the linker (AT-5'; complementary to the overhanging 5'TA of $\mathrm{pDNA}_{\mathrm{L}}$ ) are not involved in ligation with the phosphate at the $5^{\prime}-\mathrm{DNA}_{\mathrm{L}}$ end, leading to equivalent detection of $u \mathrm{DNA}_{\mathrm{L}}$ and $\mathrm{pDNA}_{\mathrm{L}}$.

\section{Analysis of the time course of 3'-processing reaction in infected cells}

For quantification of $\mathrm{pDNA}_{\mathrm{L}}$ in infected cells, the linker $11 \mathrm{TAb}$ was replaced by the linker $11 \mathrm{GTb}$ (the above mentioned linker $11 \mathrm{~b}$ is still used for $\mathrm{UDNA}_{\mathrm{L}}$ quantification in infected cells). Ligations for the different standard curves were performed in uninfected cells DNA (200 ng/ $\mu \mathrm{l})$ in order to check that the ligation/amplification efficiency was not influenced by the trapping of linker by uninfected DNA. The copy number of linear DNA was determined in reference to a standard curve prepared by amplification of quantities ranging from 10 to $10^{5}$ copies of corresponding digested fragments. PCR parameters for all PCR protocols are given in Additional file 1: Table S1B. We demonstrated that the $11 \mathrm{GTb}$ linker is able to detect the $\mathrm{uDNA}_{\mathrm{L}}$ and the $\mathrm{pDNA}_{\mathrm{L}}$ with a similar efficiency (90\%) (Figure 1B), whereas the linker $11 \mathrm{~b}$ can only detect $\mathrm{uDNA}_{\mathrm{L}}$. These two parameters have been taking into account for the calculation of $\mathrm{pDNA}_{\mathrm{L}}$ amount. Formula given the amounts of unprocessed $\mathrm{DNA}_{\mathrm{L}}\left(\mathrm{uDNA} \mathrm{A}_{\mathrm{L}}\right)$ and 3 '-processed $\mathrm{DNA}_{\mathrm{L}}$ $\left(\mathrm{pDNA}_{\mathrm{L}}\right)$ are described below:

$\mathrm{uDNA}_{\mathrm{L}}=$ amount found with the linker $11 \mathrm{~b}$, $\mathrm{pDNA}_{\mathrm{L}}=$ amount found with the linker 11GTb amount found with the linker $11 \mathrm{~b}$;

If no processing occurs (see below) the values obtained with linkers $11 \mathrm{~b}$ and $11 \mathrm{GTb}$ are identical. 


\section{Quantification of 1-LTR circles Principle}

One problem of 1-LTRc quantification is that primers hybridizing in the env and gag genes could lead to amplification of the LTR-LTR region present in 2-LTRc and amplification of $\mathrm{DNA}_{\mathrm{L}}$ via LTR recombination (see Figure 2A). In the method described below, we established PCR condition (mainly the elongation time of the PCR) which leads to specific detection of 1-LTRc.

\section{Method and validation}

For 1-LTRc quantification, reaction mixture contained $1 \times$ LightCycler FastStart DNA master Hybprobes (Roche Diagnostics), $4 \mathrm{mM} \mathrm{MgCl}$, $300 \mathrm{nM}$ of primers, and hybridization probes (200 $\mathrm{nM}$ each), in a final volume of $20 \mu \mathrm{l}$. PCR cycle conditions are shown in Additional file 1: Table S1B. Optimal elongation time for further quantitative analysis was found to be $25 \mathrm{~s}$. Amplification using 1LTR LA1 and 1LTR LA16 (Additional file 1: Table S1B) was performed with p1-LTR (Figure 2B) used as a standard curve. p2-LTR (Figure 2B) which contains two fulllength LTRs flanked by the gag and env genes was used as a control. Quantitative PCR using p1-LTR led to high amplification (92.5-100\%) and sensitive detection (200 copies $/ 10^{6}$ cells) of 1 -LTRc (Figure $2 \mathrm{C} 1$ ). Under the same condition, p2-LTR led to weak amplification (0.7-2\%), regardless of the initial amount used (Figure $2 \mathrm{C} 2$ ). Next, p2-LTR was digested using ScaI to mimic $\mathrm{DNA}_{\mathrm{L}}$ (Figure 2B). As found for p2-LTR, DNA $\mathrm{L}_{\mathrm{L}}$ amplifications was found to be negligible $(<0.1 \%)$ (Figure $2 \mathrm{C} 3)$. Taken together, our results show that our protocol is compatible with an accurate 1-LTRc quantification and overcomes the bias due to $\mathrm{DNA}_{\mathrm{L}}$ and/or 2-LTRc amplification.

Quantifications of 2-LTR circles harboring perfect or imperfect LTR-LTR junction, total HIV-1 DNA, integrated viral DNA, ß-globin gene and mitochondrial $12 \mathrm{~S}$ gene.

These real-time PCR quantifications were based on well established protocols. Sequences of primers and probes for 2-LTR circles, total HIV-1 DNA and integrated viral DNA are given in Additional file 1: Table S1B. Briefly, for 2-LTRc and total viral DNA quantifications, reaction mixtures contained $1 \times$ LightCycler FastStart DNA master Hybprobes (Roche Diagnostics), $4 \mathrm{mM} \mathrm{MgCl}_{2}$, $300 \mathrm{nM}$ of primers, and hybridization probes (200 nM each), in a final volume of $20 \mu \mathrm{l}$. PCR cycle conditions are shown in Additional file 1: Table S1B. Copy numbers of the different forms of viral DNA were determined in reference to a standard curve prepared by serial dilutions of the corresponding plasmid: p2-LTR and pNL4.3 for 2-LTRc and total viral DNA quantifications, respectively. Quantification of 2-LTRc harboring a perfect LTRLTR junction has been achieved according to De Iaco and colleagues [11]. Briefly, 2-LTRc harboring a perfect LTRLTR junction were quantified using HIV-R1: 5' -ACTGGT
ACTAGCTTGTAGCACCATCCA-3', a primer overlapping the perfect 2-LTRc junction Junct4-fwd: 5' - CAG TGTGGAAAATCTCTAGCAGTACTG-3' and two fluorogenic hybridization probes HIV-FL: 5'-CCACACA CAAGGCTACTTCCCTGA-3' and HIV-LC: 5'-TG GCAGAACTACACACCAGGGC-3'. Reaction mixtures contained $1 \times$ Light Cycler Fast Start DNA master hybridization probes (Roche Diagnostics), $4 \mathrm{mM} \mathrm{MgCl}$, $300 \mathrm{nM}$ forward and reverse primers, and $200 \mathrm{nM}$ (each) fluorogenic hybridization probe, in a final volume of $20 \mu \mathrm{l}$. PCR cycle conditions for conventional and perfect twoLTR circles HIV-1 DNA amplifications were (denaturation: $95^{\circ} \mathrm{C}, 8 \mathrm{~min}$; PCR cycles: $95^{\circ} \mathrm{C}, 10 \mathrm{~s}, 60^{\circ} \mathrm{C}, 10 \mathrm{~s}$, $72^{\circ} \mathrm{C}, 6 \mathrm{~s}$ for 50 cycles). Quantification of integrated viral DNA was performed as described previously [29]. Human ß-globin gene was quantified with commercially available materials (Control kit DNA; Roche Diagnostics). The mitochondrial $12 S$ gene was quantified using the protocol developed by Petit and colleagues [51].

\section{3'-processing of U5 extremity with radiolabeled probes}

MT4 $\left(5.10^{6}\right.$ cells) were infected with VSV-G-pseudotyped NLENG1-ES-IRES D116N or NLENG1-ESIRES WT +/- RAL, DTG or EVG (500 nM or $5 \mu \mathrm{M}$ ). $10 \mathrm{~h}$ post-infection, DNA was extracted from the cytoplasmic compartment and digested with HindIII. The digested DNA was fractionated through DNA sequencing gels. After electrophoresis, DNA was transferred on a Hybond-N + membrane (Amersham) according to manufacturer's instructions. For detection of both unprocessed and processed U5 extremity, a PCR fragment was produced with 5'-GTGCCCGTCTGTTGTGTG ACT-3' and 5' ${ }^{\prime}$-ACTGGTACTAGCTTGTAGCACCA TCCA-3' primers in the presence of $\alpha-\mathrm{CTP}^{32}$. After purification, this $\mathrm{PCR}$ probe was heated $\left(95^{\circ} \mathrm{C}, 5 \mathrm{~min}\right)$ and used for hydridization of the membrane according to the manufacturer's instructions. Then, the membrane was washed and processed for autoradiography. Southern blot in Figure S1A has been performed with DNA from MT4 cells infected with NLENG1-ES-IRES D116N. Briefly, DNA was extracted, digested with SpeI, purified and quantified using the LM-PCR and total viral DNA protocols. DNA was loaded on a $1 \%$ agarose gel and detection was performed using the PCR probe described above.

\section{Cell fractionation}

$5.10^{6}$ cells were infected with VSV-G-pseudotyped NLENG1-ES-IRES D116N. 24 h post infection, cells were harvested, washed with PBS and the pellet was resuspended in $0.5 \mathrm{~mL}$ of isotonic buffer 1 (20 mM HEPES pH 7.4, $110 \mathrm{mM} \mathrm{KCl,} 5 \mathrm{mM} \mathrm{MgCl}_{2}, 0.5 \mathrm{mM}$ EGTA, $1 \mathrm{mM}$ DTT, $20 \mu \mathrm{g} / \mathrm{ml}$ aprotinin, $20 \mu \mathrm{g} / \mathrm{ml}$ leupeptin). Samples were centrifuged for $2 \mathrm{~min}$ at $420 \mathrm{~g}$ 
$\left(4^{\circ} \mathrm{C}\right)$; the pellet was gently resuspended on ice in $50 \mu \mathrm{l}$ of isotonic buffer 1 , then $0.5 \mathrm{ml}$ isotonic buffer $+0,005 \%$ digitonine was added and samples were incubated for 5 min on ice. Following a 2 min centrifugation (420 g at $\left.4^{\circ} \mathrm{C}\right)$, the supernatant was cleared by centrifugation at $8,600 \mathrm{~g}\left(20 \mathrm{~min}\right.$ at $\left.4^{\circ} \mathrm{C}\right)$. The supernatant constitutes the cytoplasmic compartment. The pellet was washed in $0.5 \mathrm{ml}$ of isotonic buffer 1 once, resuspended in $1 \mathrm{ml}$ of isotonic buffer $2(50 \mathrm{mM}$ Tris $\mathrm{HCl} \mathrm{pH} \mathrm{7.5,} 25 \mathrm{mM} \mathrm{KCl}$, $5 \mathrm{mM} \mathrm{MgCl}_{2}, 0.25 \mathrm{M}$ sucrose) mixed with $2 \mathrm{ml}$ of isotonic buffer $2+2.3 \mathrm{M}$ sucrose and placed in a $5 \mathrm{ml} \mathrm{ul}$ tracentrifuge tube on ice. Samples were then underlayed with $1 \mathrm{ml}$ of isotonic buffer $2+2.3 \mathrm{M}$ sucrose and centrifuged at $88,000 \mathrm{~g}$ in a SW55 TI rotor at $4^{\circ} \mathrm{C}$ for $40 \mathrm{~min}$. The interface containing purified nuclei was collected. Nuclei and cytoplasmic extracts were mixed with 1 volume of $2 \times$ lysis buffer (100 mM Tris- $\mathrm{HCl} \mathrm{pH} \mathrm{8,} \mathrm{1 \%}$ SDS, $10 \mathrm{mM}$ EDTA, $50 \mu \mathrm{g} / \mathrm{ml}$ proteinase $\mathrm{K}$ ), incubated for 4 hours at $55^{\circ} \mathrm{C}$; nucleic acids were isolated by phe$\mathrm{nol} /$ chloroform and ethanol precipitation.

\section{Peptides}

Peptides used in this study (NLS-IN-Pen and SV40-NLSPen) were previously described to inhibit HIV-1 integrase nuclear import [32]. They were purchased from GeneCust at $>95 \%$ purity. HeLa cells were growth, arrested with $5 \mu \mathrm{g} / \mathrm{ml}$ of aphidicholine and then incubated with $100 \mu \mathrm{M}$ of peptide for $6 \mathrm{~h}$. Cells were then infected as above described. Viral DNA molecules were then analyzed by quantitative PCR.

\section{Mutant CTS/PPT}

The viral molecular clone, kindly provided by Dr Nathalie Arhel, used in this study is described to be impaired in the nuclear import (cPPT and CTS double mutant) due to the disruption of the FLAP structure [23].

\section{Characterization of integrase enzymatic activity in vitro} Recombinant Integrase was produced in Escherichia coli BL21-CodonPlus (DE3)RIPL (Agilent, Santa Clara, USA) and purified under non-denaturing conditions, as previously described [52]. Oligonucleotide (ODN) mimicking the U5 LTR end of the viral genome (U5B) was radiolabeled with T4 polynucleotide kinase (Biolabs, Ipswich, USA) and $\left[\gamma_{-}{ }^{32} \mathrm{P}\right]$ ATP (Amersham, GE Healthcare, USA), then purified on a Sephadex G-10 column. Doublestranded ODN was obtained by mixing equimolar amount of complementary strand in the presence of $100 \mathrm{mM}$ $\mathrm{NaCl}$. 3'-processing assay was carried out at $37^{\circ} \mathrm{C}$ in a buffer containing $20 \mathrm{mM}$ HEPES (pH 6.8), $1 \mathrm{mM}$ dithiothreitol (DTT), $7.5 \mathrm{mM} \mathrm{MgCl}_{2}$ and $50 \mathrm{mM} \mathrm{NaCl}$ in the presence of a $6.25 \mathrm{nM} \mathrm{U} 5 \mathrm{~A} / \mathrm{U} 5 \mathrm{~B}$ double-stranded DNA substrate. Products were separated by in a $16 \%$ acrylamide/urea denaturing gel, analyzed with a Typhoon
TRIO variable mode imager (GE Healthcare, USA) and quantified with ImageQuant TL software. The susceptibility of IN to RAL, EVG and DTG was determined in vitro by assessing IN activity in the presence of various concentrations of strand transfer inhibitors. 50\% inhibitory concentrations (IC50) were determined with Prism 5.0 software. The HIV-1 ODN substrate sequences were: U5B: 5'-GTGTGGAAAATCTCTAGCAGT-3'; U5A: 5' ACTGCTAGAGATTTTCCACAC-3'.

\section{Additional file}

Additional file 1: The data sets supporting the results of this article are available: Table S1, Figures S1-S6.

Competing interests

The authors declare that they have no competing interests.

\section{Authors' contributions}

Conceived and designed the experiments: SM, ED, OD. Performed the experiments: SM, ST, FS. Analyzed the data: SM, ST, FS, ED, OD. Wrote the paper: ED, OD. All authors read and approved the final manuscript.

\section{Acknowledgements}

This work was supported by ANRS (Agence Nationale de Recherche sur le Sida et les Hépatites), SIDACTION and CNRS (Centre National de la Recherche Scientifique). We thank David N. Levy for NLENG1-ES-IRES WT and NLENG1-ES-IRES D116N plasmids.

Received: 19 June 2013 Accepted: 2 August 2013

Published: 13 August 2013

\section{References}

1. Sherman MP, Greene WC: Slipping through the door: HIV entry into the nucleus. Microbes Infect 2002, 4:67-73.

2. Englund G, Theodore TS, Freed EO, Engelman A, Martin MA Integration is required for productive infection of monocyte-derived macrophages by human-immunodeficiency-virus type-1. J Virol 1995 69:3216-3219.

3. Sakai $H$, Kawamura M, Sakuragi J, Sakuragi S, Shibata R, Ishimoto A, Ono N, Ueda S, Adachi A: Integration is essential for efficient gene expression of human immunodeficiency virus type 1. J Virol 1993, 67:1169-1174.

4. Delelis O, Carayon K, Saib A, Deprez E, Mouscadet JF: Integrase and integration: biochemical activities of HIV-1 integrase. Retrovirology 2008, 5:114. doi:10.1186/1742-4690-5-114.

5. Quashie PK, Mesplede T, Wainberg MA: Evolution of HIV integrase resistance mutations. Curr Opin Infect Dis 2013, 26:43-49.

6. Calmels C, De Soultrait VR, Caumont A, Desjobert C, Faure A, Fournier M Tarrago-Litvak $L$, Parissi $V$ : Biochemical and random mutagenesis analysis of the region carrying the catalytic E152 amino acid of HIV-1 integrase. Nucleic Acids Res 2004, 32:1527-1538.

7. Engelman A, Craigie R: Identification of conserved amino-acid-residues critical for human-immunodeficiency-virus type-1 integrase functioninvitro. J Virol 1992, 66:6361-6369.

8. Hazuda DJ, Felock P, Witmer M, Wolfe A, Stillmock K, Grobler JA, Espeseth A Gabryelski L, Schleif W, Blau C, Miller MD: Inhibitors of strand transfer that prevent integration and inhibit HIV-1 replication in cells. Science 2000, 287:646-650.

9. Fricke T, Valle-Casuso JC, White TE, Brandariz-Nunez A, Bosche WJ, Reszka N, Gorelick R, Diaz-Griffero F: The ability of TNPO3-depleted cells to inhibit HIV-1 infection requires CPSF6. Retrovirology 2013, 10:46

10. Tsiang M, Jones GS, Niedziela-Majka A, Kan E, Lansdon EB, Huang W, Hung M, Samuel D, Novikov N, Xu Y, et al: New class of HIV-1 integrase 
(IN) inhibitors with a dual mode of action. J Biol Chem 2012, 287:21189-21203.

11. De laco A, Santoni F, Vannier A, Guipponi M, Antonarakis S, Luban J: TNPO3 protects HIV-1 replication from CPSF6-mediated capsid stabilization in the host cell cytoplasm. Retrovirology 2013, 10:20.

12. Kilzer JM, Stracker T, Beitzel B, Meek K, Weitzman M, Bushman FD: Roles of host cell factors in circularization of retroviral DNA. Virology 2003, 314:460-467.

13. Sloan RD, Wainberg MA: The role of unintegrated DNA in HIV infection. Retrovirology 2011, 8:52

14. Kim SY, Byrn R, Groopman J, Baltimore D: Temporal aspects of DNA and RNA synthesis during human immunodeficiency virus infection: evidence for differential gene expression. J Virol 1989, 63:3708-3713.

15. Yan N, Cherepanov P, Daigle JE, Engelman A, Lieberman J: The SET complex acts as a barrier to autointegration of HIV. Plos Pathog 2009, 1:5.

16. Sloan RD, Kuhl BD, Donahue DA, Roland A, Bar-Magen T, Wainberg MA: Transcription of preintegrated HIV-1 cDNA modulates cell surface expression of major histocompatibility complex class I via Nef. J Virol 2011, 85:2828-2836.

17. Zennou V, Petit C, Guetard D, Nerhbass U, Montagnier L, Charneau P: HIV-1 genome nuclear import is mediated by a central DNA flap. Cell 2000, 101:173-185.

18. Brussel A, Sonigo P: Analysis of early human immunodeficiency virus type 1 DNA synthesis by use of a new sensitive assay for quantifying integrated provirus. J Virol 2003, 77:10119-10124.

19. Butler SL, Hansen MST, Bushman FD: A quantitative assay for HIV DNA integration in vivo. Nat Med 2001, 7:631-634.

20. Yoder KE, Fishel R: PCR-based detection is unable to consistently distinguish HIV 1LTR circles. J Virol Methods 2006, 138:201-206.

21. Mohammed KD, Topper MB, Muesing MA: Sequential deletion of the integrase (Gag-Pol) carboxyl terminus reveals distinct phenotypic classes of defective HIV-1. J Virol 2011, 85:4654-4666.

22. Pierson TC, Zhou Y, Kieffer TL, Ruff CT, Buck C, Siliciano RF: Molecular characterization of preintegration latency in human immunodeficiency virus type 1 infection. J Virol 2002, 76:8518-8531.

23. Iglesias C, Ringeard M, Di Nunzio F, Fernandez J, Gaudin R, Souque P, Charneau P, Arhel N: Residual HIV-1 DNA Flap-independent nuclear import of CPPT/CTS double mutant viruses does not support spreading infection. Retrovirology 2011, 8:92.

24. Bukrinsky MI, Sharova N, Dempsey MP, Stanwick TL, Bukrinskaya AG, Haggerty S, Stevenson M: Active nuclear import of human immunodeficiency virus type 1 preintegration complexes. Proc Natl Acad Sci U S A 1992, 89:6580-6584.

25. Jacque JM, Stevenson M: The inner-nuclear-envelope protein emerin regulates HIV-1 infectivity. Nature 2006, 441:641-645.

26. Gelderblom HC, Vatakis DN, Burke SA, Lawrie SD, Bristol GC, Levy DN: Viral complementation allows HIV-1 replication without integration. Retrovirology 2008, 5:60. doi:10.1186/1742-4690-5-60.

27. Iyer SR, Yu D, Biancotto A, Margolis LB, Wu Y: Measurement of human immunodeficiency virus type 1 preintegration transcription by using Rev-dependent Rev-CEM cells reveals a sizable transcribing DNA population comparable to that from proviral templates. J Virol 2009, 83:8662-8673.

28. Li L, Olvera JM, Yoder KE, Mitchell RS, Butler SL, Lieber M, Martin SL, Bushman FD: Role of the non-homologous DNA end joining pathway in the early steps of retroviral infection. Embo J 2001 20:3272-3281.

29. Delelis O, Malet I, Na L, Tchertanov L, Calvez V, Marcelin AG, Subra F, Deprez E, Mouscadet JF: The G140S mutation in HIV integrases from raltegravir-resistant patients rescues catalytic defect due to the resistance Q148H mutation. Nucleic Acids Res 2009, 37:1193-1201.

30. Miller MD, Wang B, Bushman FD: Human immunodeficiency virus type 1 preintegration complexes containing discontinuous plus strands are competent to integrate in vitro. J Virol 1995, 69:3938-3944.

31. Bukrinsky Ml, Stanwick TL, Dempsey MP, Stevenson M: Quiescent lymphocytes-T as an inducible virus reservoir in Hiv-1 infection. Science 1991, 254:423-427.
32. Levin A, Armon-Omer A, Rosenbluh J, Melamed-Book N, Graessmann A, Waigmann E, Loyter A: Inhibition of HIV-1 integrase nuclear import and replication by a peptide bearing integrase putative nuclear localization signal. Retrovirology 2009, 6:112. doi:10.1186/1742-4690-6-112.

33. Arhel N, Munier S, Souque P, Mollier K, Charneau P: Nuclear import defect of human immunodeficiency virus type 1 DNA flap mutants is not dependent on the viral strain or target cell type. J Virol 2006, 80:10262-10269.

34. Dvorin JD, Bell P, Maul GG, Yamashita M, Emerman M, Malim MH: Reassessment of the roles of integrase and the central DNA flap in human immunodeficiency virus type 1 nuclear import. J Virol 2002, 76:12087-12096.

35. Limon A, Nakajima N, Lu R, Ghory HZ, Engelman A: Wild-type levels of nuclear localization and human immunodeficiency virus type 1 replication in the absence of the central DNA flap. J Virol 2002, 76:12078-12086.

36. Marsden MD, Zack JA: Human immunodeficiency virus bearing a disrupted central DNA flap is pathogenic in vivo. J Virol 2007, 81:6146-6150.

37. Marinello J, Marchand C, Mott BT, Bain A, Thomas CJ, Pommier Y: Comparison of raltegravir and elvitegravir on HIV-1 integrase catalytic reactions and on a series of drug-resistant integrase mutants. Biochemistry-Us 2008, 47:9345-9354.

38. Chen HM, Engelman A: Asymmetric processing of human immunodeficiency virus type 1 cDNA in vivo: implications for functional end coupling during the chemical steps of DNA transposition. Mol Cell Biol 2001, 21:6758-6767.

39. Nguyen BY, Isaacs RD, Teppler $H$, Leavitt RY, Sklar P, Iwamoto M, Wenning LA, Miller MD, Chen J, Kemp R, et al: Raltegravir: the first HIV-1 integrase strand transfer inhibitor in the HIV armamentarium. Ann N Y Acad Sci 2011, 1222:83-89.

40. Miller MD, Farnet CM, Bushman FD: Human immunodeficiency virus type 1 preintegration complexes: Studies of organization and composition. J Virol 1997, 71:5382-5390.

41. Katlama C, Murphy R: Dolutegravir for the treatment of HIV. Expert Opin Investig Drugs 2012, 21:523-530.

42. Marchand C: The elvitegravir Quad pill: the first once-daily dual-target anti-HIV tablet. Expert Opin Investig Drugs 2012, 21:901-904

43. Metifiot M, Maddali K, Naumova A, Zhang X, Marchand C, Pommier Y: Biochemical and pharmacological analyses of HIV-1 integrase flexible loop mutants resistant to raltegravir. Biochemistry-US 2010, 49:3715-3722

44. Yoder K, Sarasin A, Kraemer K, Mcllhatton M, Bushman F, Fishel R: The DNA repair genes $X P B$ and $X P D$ defend cells from retroviral infection. Proc Natl Acad Sci U S A 2006, 103:4622-4627.

45. Fischer M, Trkola A, Joos B, Hafner R, Joller H, Muesing MA, Kaufman DR, Berli E, Hirschel B, Weber R, Gunthard HF: Shifts in cell-associated HIV-1 RNA but not in episomal HIV-1 DNA correlate with new cycles of HIV-1 infection in vivo. Antivir Ther 2003, 8:97-104.

46. Wu YT, Marsh JW: Early transcription from nonintegrated DNA in human immunodeficiency virus infection. J Virol 2003, 77:10376-10382.

47. Bar-Magen T, Sloan RD, Faltenbacher VH, Donahue DA, Kuhl BD, Oliveira M, Xu HT, Wainberg MA: Comparative biochemical analysis of HIV-1 subtype B and C integrase enzymes. Retrovirology 2009, 6:103. doi:10.1186/1742-4690-6-103.

48. Underwood MR, Johns BA, Sato A, Martin JN, Deeks SG, Fujiwara T: The activity of the integrase inhibitor dolutegravir against HIV-1 variants isolated from raltegravir-treated adults. J Acquir Immune Defic Syndr 2012, 61:297-301.

49. Shoemaker C, Goff S, Gilboa E, Paskind M, Mitra SW, Baltimore D: Structure of a cloned circular Moloney murine leukemia virus DNA molecule containing an inverted segment: implications for retrovirus integration. Proc Natl Acad Sci USA 1980, 77:3932-3936.

50. Emiliani S, Mousnier A, Busschots K, Maroun M, Van Maele B, Tempe D, Vandekerckhove L, Moisant F, Ben-Slama L, Witvrouw M, et al: Integrase mutants defective for interaction with LEDGF/p75 are impaired in chromosome tethering and HIV-1 replication. J Biol Chem 2005, 280:25517-25523.

51. Petit C, Mathez D, Barthelemy C, Leste-Lasserre T, Naviaux RK, Sonigo P, Leibowitch J: Quantitation of blood lymphocyte mitochondrial DNA 
for the monitoring of antiretroviral drug-induced mitochondrial DNA depletion. J Acquir Immune Defic Syndr 2003, 33:461-469.

52. Delelis O, Parissi V, Leh H, Mbemba G, Petit C, Sonigo P, Deprez E,

Mouscadet JF: Efficient and specific internal cleavage of a retroviral palindromic DNA sequence by tetrameric HIV-1 integrase. Plos One 2007, 2:e608.

doi:10.1186/1742-4690-10-87

Cite this article as: Munir et al:: Quantitative analysis of the time-course of viral DNA forms during the HIV-1 life cycle. Retrovirology 2013 10:87.

\section{Submit your next manuscript to BioMed Central and take full advantage of:}

- Convenient online submission

- Thorough peer review

- No space constraints or color figure charges

- Immediate publication on acceptance

- Inclusion in PubMed, CAS, Scopus and Google Scholar

- Research which is freely available for redistribution 